\title{
COMMENTS
}

\section{A SENSE OF PURPOSE: THE ROLE OF LAW ENFORCEMENT IN FOREIGN INTELLIGENCE SURVEILLANCE}

\author{
GEORGE P. VARGHESE ${ }^{\dagger}$ \\ "They that can give up essential liberty to obtain a little temporary safety \\ deserve neither liberty nor safety." \\ "The condition upon which God hath given liberty to man is eternal \\ vigilance ...."
}

In the fall of 2002, the United States government gained a blunt new weapon in its ongoing War on Terror at the expense of the Fourth Amendment and the rights of U.S. citizens. The Foreign Intelligence Surveillance Court of Review (FISCR) met for the first time in its twenty-four year history to hear the government's appeal of an en banc lower court's unanimous interpretation of the Foreign Intelligence Surveillance Act of 1978 (FISA), as amended by provisions of the Uniting and Strengthening America by Providing Appropriate Tools Required to Intercept and Obstruct Terrorism (USA PATRIOT ACT) Act of $2001^{4}$ (commonly referred to as "Patriot

${ }^{\dagger}$ A.B. 1997, University of Chicago; J.D. Candidate 2004, University of Pennsylvania. I am grateful for all the help I received on earlier drafts of this Comment. Many thanks to my editors, Ilana Eisenstein and Laura Forman, for their insightful comments, stellar editing skills, and overall patience in guiding this Comment to coherence. Thanks are also due to the Associate Editors of the University of Pennsylvania Law Review assigned to this piece. I also owe a good deal of gratitude to Professor Catherine T. Struve for her helpful suggestions. And finally, thanks to my family and friends who continuously support me, not only in this endeavor but in all aspects of my life, beyond what I truly deserve. As is true in life, is true here, all errors are mine own.

1 BENJAMIN FRANKLIN, AN HISTORICAL REVIEW OF THE CONSTITUTION AND GOVERNMENT OF PENNSYLVANIA (London 1759), reprinted in 3 JARED SPARKS, THE WORKS OF BENJAMIN FRANKLIN 429 (Tappan, Whittemore, and Mason 1836) (citation omitted).

2 John Philpot Curran, Address before the Lord Lieutenant and Privy Council of Ireland (1790), in SPEEches of THE RIGHT HoNorable JOHN PHILPOT CurRaN, MASTER OF THE ROLLS IN IRELAND 4 (3d ed. 1811).

${ }^{3}$ 50 U.S.C. $\S \S 1801-1863(2000)$.

${ }^{4}$ Pub. L. No. 107-56, 115 Stat. 272 (2001) [hereinafter Patriot Act]. 
Act"). On November 18, 2002, FISCR issued its first opinion, ${ }^{5}$ overruling the Foreign Intelligence Surveillance Court's (FISC) statutory interpretation of FISA and upholding the constitutionality of the Patriot Act's "significant purpose" test, a test which relaxes the barriers between law enforcement and intelligence investigations.

As a result of this ruling, law enforcement investigators can now bypass the ordinary Fourth Amendment and Title III ${ }^{6}$ surveillance requirements by invoking a foreign intelligence purpose as a pretext for obtaining a FISA warrant to use in a criminal investigation. ${ }^{7}$ The effect of this power is that U.S. citizens now face the threat of secret law enforcement investigations based on FISA warrants issued without any showing of probable cause of criminal activity. ${ }^{8}$ The warrants are granted in ex parte, in camera proceedings that are subject neither to discovery by the defendant nor meaningful suppression review by district courts. This is an unconstitutional price that is too high to pay, even in the name of post-September 11 national security. ${ }^{9}$

This Comment examines the FISCR opinion and calls into question the constitutionality of the Patriot Act's "significant purpose" test. Part I discusses the background of the foreign intelligence exception to the Fourth Amendment warrant requirement. Part II

${ }^{5}$ In re Sealed Case, 310 F.3d 717 (Foreign Intelligence Surveillance Ct. Rev. 2002) (per curiam), cert. denied, 123 S. Ct. 1615 (2003).

${ }^{6}$ Pub. L. No. 90-351, 82 Stat. 197, 211-25 (codified as amended at 18 U.S.C. $\S \S 2510-2522(2000)$ ) [hereinafter Title III].

${ }^{7}$ While the case before the FISCR only dealt with electronic surveillance, the ruling also would apply to physical searches conducted under FISA. FISA originally permitted only electronic surveillance, but was amended in 1995 to include physical searches. See 50 U.S.C. $\$ \$ 1821-1829$ (allowing the president to authorize physical searches without a court order). The provisions covering physical searches under FISA mirror those covering electronic surveillance. Thus, while this paper refers to electronic surveillance throughout, the same arguments are applicable to physical searches under FISA.

${ }^{8}$ Although FISA applies to surveillance of both U.S. and non-U.S. persons, this article addresses the impact primarily on U.S. citizens and permanent resident aliens.

${ }^{9}$ Political leaders have begun to reach this conclusion as well. On July 31,2003 , Senators Lisa Murkowski and Ron Wyden introduced a bill that would reinstate the primary purpose test by amending the language of FISA to require foreign intelligence to be "the primary purpose" of a FISA investigation, rather than "a significant purpose" as required by the Patriot Act. S. 1552, 108th Cong. $\S 10$ (2003). See also Murkowski Introduces Bill to Change USA Patriot Act, WHITE HOUSE BULL., (Bull. News Network, Vienna, Va.) Aug. 1, 2003, at 1 ("We must strike a careful and constitutional balance between protecting the individual rights of Americans and giving our law enforcement and intelligence officials the tools they need to prevent future terrorist attacks. To date it appears portions of the Patriot Act may have moved the scales out of balance." (quoting Senator Murkowski)). At the time of this writing, the bill was referred to the Judiciary Committee. 
details the passage of FISA and the evolution of its interpretation by the courts and the executive branch. Part III focuses on the Patriot Act's amendments to FISA in light of the expanded needs to combat terrorism, and both the government's argument and the FISCR opinion upholding its constitutionality. Finally, Part IV evaluates the validity of these arguments in light of the history of the foreign intelligence exception, Title III, and the "special governmental needs" doctrine and concludes that the FISCR erred in its ruling.

\section{THE FOREIGN INTELLIGENCE EXCEPTION AND THE FISA DOCTRINE}

\section{A. The Birth of a Constitutional and Statutory National Security Exception}

The Fourth Amendment protects U.S. citizens from governmental intrusion by providing that " $[\mathrm{t}]$ he right of the people to be secure in their persons, houses, papers, and effects, against unreasonable searches and seizures, shall not be violated." ${ }^{\prime 0}$ In the landmark case Katz v. United States, ${ }^{11}$ the Supreme Court held that electronic surveillance constitutes a search for purposes of the Fourth Amendment and, therefore, cannot be conducted by the government without a showing of probable cause and a warrant issued by a neutral and detached magistrate. ${ }^{12}$ The Court reaffirmed its long-held view that searches conducted without a warrant are "per se unreasonable under the Fourth Amendment-subject only to a few specifically established and well-delineated exceptions."

In a footnote, however, the Court expressly passed on the issue of whether the Fourth Amendment requires prior judicial authorization of surveillance in cases involving national security. ${ }^{14}$ In his concur-

${ }^{10}$ U.S. CONST. amend. N.

11389 U.S. 347 (1967).

${ }^{12} I d$. at $356-57$.

${ }^{13} I d$. at 357 (footnote omitted).

${ }^{14}$ Id. at 358 n.23; see also STEPHEN DyCUS ET AL., NATIONAL SECURITY LAW 61415 (3d ed. 2002) (discussing the Katz footnote and the development of the national security exception); William C. Banks \& M.E. Bowman, Executive Authority for National Security Surveillance, 50 AM. U. L. REv. 1, 48-49 (2000) (noting that the Supreme Court explicitly declined to extend the Katz holding to cases involving national security and the effect of this omission on the Title III statutory framework); Americo $\mathbf{R}$. Cinquegrana, The Walls (and Wires) Have Ears: The Background and First Ten Years of the Foreign Intelligence Surveillance Act of 1978, 137 U. PA. L. REV. 793, 800 (1989) ("The Court's gratuitous discussion in Katz regarding surveillance activities undertaken in furtherance of national security interests was critical to the development of FISA."); Sharon H. Rackow, Comment, How the USA Patriot Act Will Permit Governmental Infringement upon the Privacy of Americans in the Name of "Intelligence" Investigations, $150 \mathrm{U}$. 
rence, Justice White more explicitly suggested that the Court "should not require the warrant procedure if the President of the United States or his chief legal officer, the Attorney General, has considered the requirements of national security and authorized electronic surveillance as reasonable."

Justice Douglas, however, in a separate concurrence joined by Justice Brennan, adamantly rejected any notion of a national security exception to the Fourth Amendment, believing it would give a "green light for the Executive Branch to resort to electronic eavesdropping without a warrant in cases which the Executive Branch itself labels 'national security' matters." ${ }^{16}$ Justice Douglas noted that the president and the attorney general are "properly interested parties, cast in the role of adversary, in national security cases." ${ }^{17}$ Furthermore, "spies and saboteurs are as entitled to the protection of the Fourth Amendment as suspected gamblers." ${ }^{18}$ Therefore, Justice Douglas concluded, the Fourth Amendment rights of national security suspects could not be assured "when the President and Attorney General assume both the position of adversary-and-prosecutor and disinterested, neutral magistrate. ${ }^{, 19}$

Seeking to establish uniform procedures by which law enforcement may conduct electronic surveillance in accordance with the Katz ruling, Congress passed Title III of the Omnibus Crime Control and Safe Streets Act of 1968 (Title III). ${ }^{20}$ Title III codifies the Katz decision by requiring probable cause before the government may conduct electronic surveillance-entailing both that the suspect may commit, or has committed, a criminal offense, and that the targeted facility is connected with that offense. ${ }^{21}$ Most significantly, Title III permits authorization of a warrant only upon judicial determination of probable cause and upon government compliance with a strict

PA. L. REV. 165l, 1658 (2002) (noting that the Court's "highly controversial footnote ... left the door open for warrantless surveillance in circumstances concerning national security").

${ }^{15} 389$ U.S. at 364 (White, J., concurring).

${ }^{16}$ Id. at 359 (Douglas, J., concurring).

${ }^{17} I d$. at 360 (Douglas, J., concurring).

18 Id. (Douglas, J., concurring).

${ }^{19}$ Id. (Douglas, J., concurring).

${ }^{20}$ Pub. L. No. 90-351, 82 Stat. 197, $211-25$ (codified as amended at 18 U.S.C. $\S \S 2510-2522(2000))$.

${ }^{21} 18$ U.S.C. $\$ 2518(1)$. 
procedural regime designed both to protect the integrity of surveillance evidence and to limit government intrusion on privacy. ${ }^{22}$

While Title III was meant to be the exclusive means by which law enforcement could conduct electronic surveillance, Congress specifically excluded from its reach executive officials conducting investigations dealing with national security matters. The statute stated that:

[N]othing contained in this chapter... shall limit the constitutional power of the President to take such measures as he deems necessary to protect the Nation against actual or potential attack or other hostile acts of a foreign power, to obtain foreign intelligence information deemed essential to the security of the United States, or to protect national security information against foreign intelligence activities. Nor shall anything contained in this chapter be deemed to limit the constitutional power of the President to take such measures as he deems necessary to protect the United States against the overthrow of the Government by force or other unlawful means, or against any other clear and present danger to the structure or existence of the Government. ${ }^{29}$

\section{B. Keith and Limitations on the National Security Exception}

Four years later, in United States v. United States District Court (Keith), ${ }^{24}$ the Supreme Court returned to the issue it left open in the Katz footnote and clarified the Fourth Amendment's national security exception. In Keith, the government sought to prosecute three citizens who were conspiring to bomb an office of the Central Intelligence Agency in Ann Arbor, Michigan. ${ }^{25}$ In pretrial proceedings, the defendants moved to compel the government to disclose electronic surveillance conducted without a warrant to determine

${ }^{22}$ See id. $\$ 2518$ (setting forth the procedural requirements and probable cause standard for judicial authorization of electronic surveillance).

${ }^{23} \mathrm{Id}$. $\$ 2511$ (3) (repealed 1978). This section was repealed in 1978 following the passage of FISA.

${ }^{24} 407$ U.S. 297 (1972); see also Banks \& Bowman, supra note 14, at 49-53 (summarizing the Keith decision and the Supreme Court's differentiation of the president's power under the national security exception in situations involving domestic organizations); Cinquegrana, supra note 14, at 803 (noting that while Keith "rejected the government's arguments that courts lacked the necessary expertise and security to evaluate this type of intelligence activity, it emphasized that its holding did not extend to surveillance involving foreign powers or their agents"); Rackow, supra note 14, at 1662 ("Although the Court acknowledged the Executive's intelligencegathering authority, it held that the Fourth Amendment does not permit warrantless wiretaps in cases involving domestic threats to national security.").

${ }^{25} 407$ U.S. at 299. 
whether it had tainted any potential trial evidence. ${ }^{26}$ The Attorney General admitted to the surveillance but argued that it was for intelligence-gathering purposes and therefore fell under the national security exception to the Fourth Amendment, as codified in $\S 2511$ (3) of Title III, and did not need not be disclosed to the defendants. ${ }^{27}$ The government claimed the defendant's actions posed a "clear and present danger to the structure or existence of the Government..",28 The district court disagreed, finding the surveillance to be a violation of the Fourth Amendment and ordered disclosure. ${ }^{29}$ In affirming the lower court's ruling, the Supreme Court held that the language in $\S 2511(3)$ of Title III neither limited nor augmented presidential power, but rather that "Congress simply left presidential powers where it found them." ${ }^{30}$ Therefore, the issue was whether the president had inherent constitutional authority to order warrantless surveillance of domestic organizations for national security purposes as an exception to the Fourth Amendment. ${ }^{31}$

In answering this question, the Supreme Court recognized that national security investigations could implicate both First and Fourth Amendment interests to an even greater degree than cases involving ordinary crime. ${ }^{32}$ While the Constitution charges the president with the obligation to "preserve, protect and defend the Constitution of the United States," national security investigations also involve "greater jeopardy to constitutionally protected speech." As a result, Justice Powell concluded that the Court must balance "the duty of Government to protect the domestic security, [with] the potential danger posed by unreasonable surveillance to individual privacy and free expression." ${ }^{35}$ The Court described this danger as:

[T] he tendency of Government-however benevolent and benign its motives-to view with suspicion those who most fervently dispute its policies. Fourth Amendment protections become the more necessary when the targets of official surveillance may be those suspected of unorthodoxy in their political beliefs. The danger to political dissent is

26

${ }^{27}$ Id. at 301 .

${ }^{28} I d$. at 302 (quoting 18 U.S.C. $\$ 2511(3)$ ).

${ }^{29}$ United States v. Sinclair, 321 F. Supp. 1074, 1080 (E.D. Mich. 1971).

30407 U.S. at 303.

${ }^{31} I d$. at 299.

${ }^{32}$ Id. at 313.

${ }^{33}$ U.S. CONST. art. II, $\S 1, \mathrm{cl} .8$.

${ }^{34} 407$ U.S. at 313.

${ }^{35} I d$. at 314-15. 
acute where the Government attempts to act under so vague a concept as the power to protect "domestic security." Given the difficulty of defining the domestic security interest, the danger of abuse in acting to protect that interest becomes apparent.

The Court thus adopted Justice Douglas' reasoning in his Katz concurrence and held that the Fourth Amendment does not distinguish between various substantive offenses and that its "freedoms cannot properly be guaranteed if domestic security surveillances may be conducted solely within the discretion of the Executive Branch." ${ }^{37}$ Because the potential for abuse was so great and the rights protected were so fundamental, the Court held that, in intelligence-gathering investigations involving domestic organizations, the Fourth Amendment required the executive branch to have probable cause of criminal wrongdoing and to seek judicial authorization prior to conducting electronic surveillance. ${ }^{38}$

While the Keith ruling would seem to be definitive, it did not entirely resolve the issue of warrantless national security surveillance in the United States. The Keith case involved purely domestic organizations where there was "no evidence of any involvement, directly or indirectly, of a foreign power." ${ }^{39}$ Specifically, the Court stated that its opinion did not pass "judgment on the scope of the President's surveillance power with respect to the activities of foreign powers, within or without this country." ${ }^{00}$ Therefore, circuit courts continuously have held that Keith merely narrowed the larger nationalsecurity exception to a more limited foreign intelligence exception to the Fourth Amendment.

\section{The Circuit Courts Define the Foreign Intelligence Exception}

Following Keith, five federal circuit courts of appeals reviewed cases involving the president's constitutional power to conduct warrantless electronic surveillance for foreign intelligence purposes. ${ }^{41}$

${ }^{36} I d$. at 314 .

${ }^{37}$ Id. at 316-17; see also Katz v. United States, 389 U.S. 347, 359-60 (1960) (Douglas, J., concurring) (opining that there is "no distinction under the Fourth Amendment between types of crimes").

38 Id. at 321 .

39 Id. at 309.

Id . at 308.

41 See Dycus ET AL., supra note 14, at 626-27 (discussing the post-Keith circuit court cases involving warrantless foreign intelligence surveillance); Banks \& Bowman, supra note 14, at 56-57 (explaining that the proper balance between the First and Fourth 
Four of the five courts of appeals addressing this issue upheld the Executive Branch's arguments supporting the constitutionality of a foreign intelligence exception to the Fourth Amendment warrant requirement. The circuit courts found constitutional authority for the exception based on the president's inherent power as commander in chief $^{42}$ and his role as the "sole organ of the federal government in the field of international relations." ${ }^{43}$

In 1973, one year after Keith was decided, the Fifth Circuit addressed the same issue in United States $v$. Brown. ${ }^{44}$ In Brown, the Fifth Circuit upheld the legality of warrantless surveillance when initiated for the purpose of gathering foreign intelligence. ${ }^{45}$ Although the defendant in Brown was not the target of the investigation, the government did intercept several of his conversations during its surveillance. ${ }^{46}$ At the defendant's subsequent criminal trial, the court refused to compel disclosure of the evidence, stating only that it was not in the national interest and that the surveillance was made "in connection with obtaining foreign intelligence information., ${ }^{47}$ In upholding a foreign intelligence exception, the appellate court stated that, "because of the President's constitutional duty to act for the United States in the field of foreign relations, and his inherent power to protect national security in the context of foreign affairs[,] ... the President may constitutionally authorize warrantless wiretaps for the purpose of gathering foreign intelligence." ${ }^{48}$ In distinguishing the facts of the case from Keith, the appellate court stated that "[r]estrictions upon the President's power which are appropriate in cases of domestic security become artificial in the context of the

\footnotetext{
Amendment rights of individuals and the government's interest in protecting national security is resolved by the FBI's "fact-sensitive inquiries, without clear judicial criteria for deciding when prior judicial warrant is required"); Cinquegrana, supra note 14, at 804 (suggesting that courts recognizing the foreign intelligence exception did so out of "concern for the efficiency and expertise of the nation's foreign intelligence process and the deleterious effects that might result from judicial interference"); Rackow, supra note 14, at 1665 (describing the D.C. Circuit Court of Appeals opinion that other courts addressing the issue had "simply converted the Executive's need to gather intelligence information into an absolute right to conduct warrantless surveillance -without giving sufficient thought to First and Fourth Amendment interests that may be infringed upon by allowing the Executive to bypass judicial scrutiny").

${ }^{42}$ U.S. CONST. art. II, $\$ 2$, cl. 1.

${ }^{49}$ United States v. Curtiss-Wright Export Corp., 299 U.S. 304, $320-22$ (1936).

44 484 F.2d 418 (5th Cir. 1973).

${ }^{45}$ Id. at 426.

${ }^{40}$ Id. at $424-25$.

${ }^{47}$ Id. at 427.

${ }^{48} I d$.
} 
international sphere." ${ }^{49}$ In his concurrence, Judge Goldberg agreed with the majority's reasoning, but cautioned that it was the "essential burden of the courts to be ever vigilant, so that foreign intelligence never becomes a pro forma justification for any degree of intrusion into zones of privacy guaranteed by the Fourth Amendment. ${ }^{, 50}$

The following year, the Third Circuit, sitting en banc, addressed the same issue in United States $v$. Butenko, ${ }^{51}$ which involved the electronic surveillance of a Soviet national working with an American citizen to obtain sensitive information regarding United States foreign policy and military capabilities. ${ }^{52}$ As in Brown, the Third Circuit found that the president's constitutional authority to conduct foreign intelligence investigations was "implied from his duty to conduct the nation's foreign affairs. ${ }^{, 53}$ However, the court qualified this statement by adding that, although national security threats are of immeasurable gravity, there is "nothing in the language of the Constitution to justify completely removing the Fourth Amendment's requirements in the foreign affairs field. ${ }^{54}$ Thus, the court determined that, while prior judicial authorization would interfere too much with the executive's foreign affairs power, post-search judicial review represented an important safeguard of Fourth Amendment rights and a deterrent to potential abuse. ${ }^{5 J}$ Further, the Third Circuit held that the district court, "when reviewing a particular search must, above all, be assured that [securing foreign intelligence information] was in fact its primary purpose and that the accumulation of evidence of criminal activity was incidental. ${ }^{56}$

In United States v. Truong Dinh Hung, ${ }^{57}$ the Fourth Circuit faced for the first time the constitutional issue of whether or not the government can use information collected from warrantless foreign

49 Id. While ultimately limiting its holding to domestic security concerns, Keith explicitly recognizes a distinction between domestic and foreign national security and surveillance. 407 U.S. at 308, 321-22.

50) Brown, 484 F.2d at 427 (Goldberg, J., concurring).

494 F.2d 593 (3d Cir. 1974).

${ }^{52}$ Id. at 596 .

${ }^{53} I d$. at 603 .

${ }^{54}$ Id.

Id. at 605-06.

${ }^{56}$ Id. at 606 (emphasis added); see also United States v. Buck, 548 F.2d 871, 875 (9th Cir. 1977) (upholding the foreign intelligence exception (citing Butenko, 494 F.2d at $605-06)$ ).

${ }^{57} 629$ F.2d 908 (4th Cir. 1980) [hereinafter Truong]. Though the case was decided in 1980, it involved surveillance which was conducted in 1977-1978, prior to the enactment of FISA. Id. at 912. FISA, therefore, was not yet applicable. 
intelligence surveillance in a criminal prosecution. ${ }^{58}$ David Truong, a Vietnamese national, conspired with Ronald Humphrey, a U.S. citizen and employee of the United States Information Agency, to pass on classified information dealing with U.S. policy in Southeast Asia to the North Vietnamese during the 1977 Paris peace negotiations. ${ }^{59}$ Unbeknownst to Truong, the courier he used to transport the confidential information to the North Vietnamese in Paris was an informant employed by the Foreign Bureau of Intelligence (FBI) and the Central Intelligence Agency (CIA) ${ }^{60}$ For more than a year, the agencies conducted intense surveillance of Truong in order to locate the source of the information leak. ${ }^{61}$ Though the surveillance was authorized by the Attorney General, it was conducted without a warrant or prior judicial approval. ${ }^{62}$ At trial, the defendants argued that the foreign intelligence exception should apply only when the surveillance is conducted solely for foreign intelligence purposes, and therefore, all evidence obtained without a warrant should be suppressed. ${ }^{63}$ The government countered that the foreign intelligence exception should apply when surveillance is conducted for any foreign intelligence reason, and therefore, the fruits of that surveillance should be admitted at trial. ${ }^{64}$

Rejecting both parties' arguments, the Fourth Circuit noted that "almost all foreign intelligence investigations are in part criminal investigations, ${ }^{, 65}$ and therefore neither party's approach is acceptable. Thus, the court ruled that the foreign intelligence exception applies "only when the surveillance is conducted 'primarily' for foreign intelligence reasons." foreign intelligence exception was necessary

because[,] once surveillance becomes primarily a criminal investigation, the courts are entirely competent to make the usual probable cause determination, and because, importantly, individual privacy interests come to the fore and government foreign policy concerns recede when

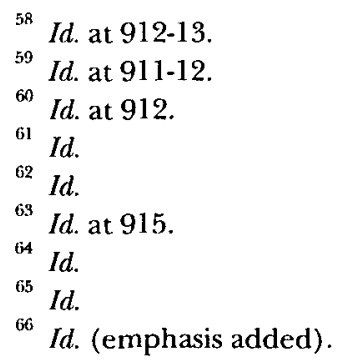


the government is primarily attempting to form the basis for a criminal prosecution.

The court affirmed the district court determination that, when the Criminal Division of the Justice Department took over a central role in the investigation from counterintelligence officials, its focus became primarily criminal in nature. ${ }^{68}$ As a result, all evidence obtained by the government through warrantless surveillance after that point was suppressed. $^{69}$

While the circuit courts in each of the cases above upheld the lawfulness of a foreign intelligence exception, in Zweibon v. Mitchell, ${ }^{70}$ the D.C. Circuit, sitting en banc, refused to follow suit. In Zweibon, members of the Jewish Defense League (JDL), who were the subjects of warrantless electronic surveillance, brought a Bivens action ${ }^{71}$ against the Attorney General for violation of their Fourth Amendment rights. $^{72}$ The JDL was a domestic organization, whose focus "was primarily directed at opposing the Soviet government's restrictive emigration policies. ${ }^{73}$ The government argued that, by perpetrating violent acts against Soviet officials and installations in the United States, the JDL was causing international embarrassment, interfering with peaceful relations between the United States and the Soviet Union, and risking possible Soviet retaliation against American citizens in Moscow. ${ }^{74}$ For these reasons, warrantless surveillance of the group was proper under the foreign intelligence exception. ${ }^{75}$ The D.C. Circuit rejected the government's argument, reaffirming Keith:

A warrant must be obtained before a wiretap is installed on a domestic organization that is neither the agent of nor acting in collaboration with a foreign power, even if the surveillance is installed under presidential directive in the name of foreign intelligence gathering for protection of the national security.

${ }^{67} I d$.

${ }^{68}$ Id. at 916 .

69 Id.

${ }^{70}$ 516 F.2d 594 (D.C. Cir. 1975).

7 See Bivens v. Six Unknown Named Agents, 403 U.S. 388, 397 (1971) (finding that a plaintiff has a private right of action under the Fourth Amendment to bring suit to recover damages if her rights protected by that amendment have been violated by federal officials).

${ }^{72} 516$ F.2d at 605.

${ }^{73}$ Id. at 608 .

${ }^{74}$ Id. at $607-09$.

${ }^{75}$ Id. at 608 .

${ }^{76}$ Id. at 614 . 
In dicta, a plurality of the court went even further, concluding that "absent exigent circumstances, all warrantless electronic surveillance is unreasonable and therefore unconstitutional."

By the end of the 1970 s, the national security exception to the Fourth Amendment, first identified in Katz, was refined to a foreign intelligence exception limited to investigations against foreign powers and agents of foreign powers. Four out of the five circuit courts that had addressed the issue upheld this more limited foreign intelligence exception as constitutional under both the president's powers as commander in chief and his sole responsibility for the foreign affairs of the nation. Furthermore, the circuit courts limited the exception to instances where the primary purpose of the investigation was foreign intelligence. Provided that surveillance fell within the foreign intelligence exception, Truong then permitted the fruits of such an investigation to be used against defendants during a criminal trial. ${ }^{78}$ Despite the importance of the issues at stake and the split among the circuits, the Supreme Court did not address the issue of foreign intelligence beyond its indirect statements in Katz and Keith. ${ }^{79}$ By 1978, however, Congress entered the debate.

\section{THE EVOLUTION OF THE FISA DOCTRINE}

\section{A. Historical Background to FISA}

During the 1970s, Congress took a closer look at the Executive Branch's use of warrantless surveillance following revelations of highprofile abuses of power such as the Watergate break-in ${ }^{80}$ and the White House "enemies" list. ${ }^{81}$ In 1976, the Senate Select Committee to Study Governmental Operations with Respect to Intelligence Activities (the "Church Committee") issued a report cataloging a litany of occasions when intelligence activities had "exceeded the restraints on the exercise of governmental power which are imposed by our country's

77 Id.

${ }^{78} 629$ F.2d at 916.

${ }^{79}$ See supra Part I.A-B (discussing the evolution of the national security exception).

${ }^{80}$ See Cinquegrana, supra note 14 , at 806 (discussing the antagonistic mood in Congress following the Watergate scandal).

${ }^{81}$ See Anita Bernstein, Note, Executive Targeting of Congressmen as a Violation of the Arrest Clause, 94 YALE L.J. 647, 649 n.10 (1985) (listing politicians whose names appeared on President Nixon's White House enemies list used as a reference by the administration to identify and harass his political enemies). 
Constitution, laws and traditions., ${ }^{, 2}$ The report revealed widespread and flagrant abuse of power by FBI and CIA officials against U.S. citizens who participated in domestic political organizations including the Women's Liberation Movement, Students for a Democratic Society, Black Student Unions, the NAACP, and the anti-war movement. $^{83}$

These national security investigations were conducted "against United States citizens who were not readily identifiable as reasonable sources of foreign intelligence information, who appeared to pose little threat to the national security, and who were not alleged to be involved in any criminal activity. ${ }^{84}$ Between 1960 and 1974, there were more than 500,000 separate FBI counterintelligence investigations of persons or groups under suspicion of being subversives, yet not a single person or group was ever prosecuted during this period. ${ }^{85}$ However, during these investigations, the FBI undertook steps to discredit individuals, manipulate the media's perception of the groups, distort data to influence government policy, and generally chill the individuals' First Amendment rights to free speech and association. ${ }^{86}$ In addition to legal violations, the report detailed examples of FBI "transgressions against human decency" including:

the smear campaign against Dr. Martin Luther King, Jr., the testing of dangerous drugs on unsuspecting American citizens, the dissemination of information about the sex lives, drinking habits, and marital problems of electronic surveillance targets, and the COINTELPRO attempts to turn dissident organizations against one another and to destroy marriages. ${ }^{87}$

82 S. REP. NO. 94-755, bk. II, at 2 (1976); see Cinquegrana, supra note 14, at 806 (noting that the Church Committee "uncovered far-ranging infringements upon individual privacy interests," especially through the use of warrantless electronic surveillance).

${ }^{83}$ S. REP. NO. 94-755, bk. II, at 7-9 (1976).

${ }^{84}$ Cinquegrana, supra note 14 , at 807.

${ }^{85}$ S. REP. NO. 94-755, bk. II, at 19 (1976).

${ }^{86} I d$. at $9,139$.

${ }^{87}$ Id. at 140; see also Steven W. Becker, Maintaining Secret Government Dossiers on the First Amendment Activities of American Citizens: The Law Enforcement Activity Exception to the Privacy Act, 50 DEPAul L. REV. 675, 681 (noting that Senator Gaylor Nelson had referred to the FBI's COINTELPRO operation as a clandestine program in which the FBI conducted undercover surveillance). COINTELPRO, the FBI's acronym for counterintelligence program, was a series of covert actions taken by the FBI over a fifteen-year period to "disrupt" and "neutralize" domestic groups and individuals. S. REP. NO. 94-755, bk. III, at 3-4 (1976). The FBl's tactics used in COINTELPRO were 
The report noted that the intelligence community's "general attitude was that intelligence needs were responsive to a higher law... the greater good, the national security. ${ }^{\text {s8 }}$

In response to these widespread and flagrant violations, the Church Committee stated unequivocally in its conclusions and recommendations its belief regarding activities such as warrantless surveillance or searches that " $[t]$ here is no inherent constitutional authority for the President or any intelligence agency to violate the law." ${ }^{89}$ The Committee strongly recommended that Congress create a statutory framework to regulate the use of electronic surveillance for intelligence purposes within the United States by amending Title III to require warrants for all electronic surveillance. ${ }^{90}$ The Church Committee concluded that only by requiring a judicial warrant, and removing counterintelligence electronic surveillance from the unchecked discretion of the executive, could the flagrant abuses of power be eliminated. ${ }^{91}$

\section{B. Passage of FISA}

In 1978, Congress acted upon the Church Committee's recommendation and passed FISA as the exclusive means by which the executive branch may conduct electronic surveillance for foreign intelligence purposes within the United States. ${ }^{92}$ Specifically, FISA limits electronic surveillance to investigations of a foreign power or agents of a foreign power for the purpose of obtaining foreign intelligence information. ${ }^{93}$ Congress included within the definition of a "foreign power," not only a foreign government, but also "a group

the same as those used against hostile foreign agents-“clandestine activities intended to influence political choices and social values." Id. at 4 . COINTELPRO was the result of pressure on the FBI to do something about a perceived threat that law enforcement techniques could not address because of the Supreme Court's imposition of constitutional restrictions. Id. at 10-11. There were five recognized threats to domestic security that COINTELPRO programs targeted: the Communist Party USA program, the Socialist Workers Party program, the White Hate Group program, the Black Nationalist Hate Group program, and the New Left program. Id. at 4.

${ }^{88}$ S. REP. NO. 94-755, bk. III, at 145 (1976).

89 . at 297.

Id. at $327-28$.

${ }^{91}$ See id. at 325,327 (noting that with a warrant requirement "the dangerous doctrine of inherent Executive power to target an American for electronic surveillance can be put to rest at last.").

50 U.S.C. $\$ \S 1801-1863(2000)$.

${ }^{0.3} I d$. 
engaged in international terrorism or activities in preparation therefor. ${ }^{\prime 4}$ The term "international terrorism" is defined as activities that:

(1) involve violent acts or acts dangerous to human life that are a violation of the criminal laws of the United States or of any State, or that would be a criminal violation if committed within the jurisdiction of the United States or any State;

(2) appear to be intended-

(A) to intimidate or coerce a civilian population;

(B) to influence the policy of a government by intimidation or coercion; or

(C) to affect the conduct of a government by assassination or kidnapping; and

(3) occur totally outside the United States, or transcend national boundaries in terms of the means by which they are accomplished, the persons they appear intended to coerce or intimidate, or the locale in which their perpetrators operate or seek asylum.

The Act authorizes electronic surveillance as long as the government can demonstrate that the target is a foreign power or an agent of a foreign power (defined as a non-United States person acting within the United States for or on behalf of a foreign power) engaged in clandestine intelligence activities within the country contrary to United States interests. ${ }^{96}$ Congress created a heightened threshold for intelligence investigations of U.S. persons (defined as citizens or permanent residents) ${ }^{97}$ by requiring that they "knowingly engage" in the proscribed activity before permitting surveillance." Thus, a U.S. citizen can be found to be an agent of a foreign power if she (a) "knowingly engages in clandestine intelligence" activities, which may violate U.S. criminal laws on behalf of a foreign power; (b) "knowingly engages in sabotage or international terrorism, or activities that are in preparation therefor, for or on behalf of a foreign power"; or (c) "knowingly aids or abets any person" conducting such activities. $^{99}$ Surveillance is permitted solely for the purpose of obtaining "foreign intelligence information," which is "information that relates to, and if concerning a United States person is necessary to, the ability of the United States to protect against" (a) actual or

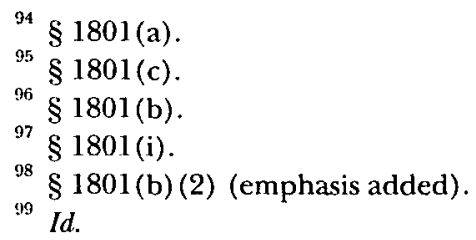


potential attack by a foreign power; (b) sabotage or international terrorism; or (c) clandestine intelligence activities by a foreign power or its agent. ${ }^{100}$ Foreign intelligence information can also be "information with respect to a foreign power... that relates to, and if concerning a United States person is necessary to (a) the national defense or the security of the United States; or (b) the conduct of the foreign affairs of the United States."101

Pursuant to its Article III power, ${ }^{102}$ Congress established the FISC, comprised of seven district court judges appointed by the Chief Justice. ${ }^{103}$ The FISC has jurisdiction to consider applications and grant orders for electronic surveillance targeting a foreign power or agent of a foreign power to obtain foreign intelligence information within the United States. ${ }^{104}$ The Act establishes a procedure by which a federal officer must submit an application for an order approving electronic surveillance, including a certification "that the purpose of the surveillance is to obtain foreign intelligence information." 10.5

The FISC judge reviews the application for electronic surveillance in an ex parte, secret proceeding. ${ }^{106}$ Under FISA, a FISC judge must issue an order authorizing the electronic surveillance if, based on the facts established in the application, there is probable cause to believe that the target is a foreign power or an agent of a foreign power and that she is using, or about to use, the facilities targeted by the surveillance. ${ }^{107}$ Thus, unlike Title III, FISA grants little discretion to the FISC judges in approving a surveillance request. ${ }^{108}$

${ }^{100} \S 1801(\mathrm{e})$.

101 Id.

${ }^{102}$ See U.S. CONST. art. III, $\$ 1$ ("The judicial power of the United States, shall be vested in one Supreme Court, and in such inferior Courts as the Congress may from time to time ordain and establish.").

${ }^{103} 50$ U.S.C. $\$ 1803$ (a) (2000). The Patriot Act later amended this section by expanding the number of FISC judges from seven to eleven. Patriot Act, Pub. L. No. 107-56, § 208, 115 Stat. 291 (2001).

${ }^{104} 50$ U.S.C. $\$ 1803(\mathrm{a})$.

${ }^{105} I d . \S 1804(\mathrm{a})(7)(\mathrm{B})$ (emphasis added).

106 Id. $\$ 1805$.

$107 \S 1805(\mathrm{a})(1)-(3)$.

108 Title III provides that a judge may enter an ex parte order authorizing surveillance if there is probable cause for belief that (a) "an individual is committing, has committed, or is about to commit a particular offense;" (b) particular communications concerning the offense will be intercepted; (c) normal investigative techniques have tried and failed or will not be effective, and (d) the facilities targeted are used, or are about to be used, in commission of such an offense. 18 U.S.C. $\$$ 2518(3) (2000). Clearly, judges reviewing the Title III applications have far greater 
In its report on the bill, the House specifically stated that "when reviewing the certifications ... unless there is a prima facie showing of a fraudulent statement by a certifying officer, procedural regularity is the only determination to be made if a non-U.S. person is the target." the target is a U.S. person, a FISC judge has the additional minimal responsibility of ensuring the certification is not "clearly erroneous."

\section{The Use of FISA Information for Law Enforcement Purposes}

FISA provides for electronic surveillance solely in foreign intelligence investigations and requires that the attorney general adopt procedures to minimize the dissemination of information gathered during an investigation against a U.S. person."' Despite these limitations, FISA nevertheless allows the fruits of electronic surveillance to be used in a subsequent criminal trial in certain circumstances.

Specifically, FISA establishes that information gathered during a foreign intelligence investigation may be used for law enforcement purposes if authorized by the attorney general, ${ }^{12}$ and notice is given to the defendant. ${ }^{13}$ A defendant may move to suppress the evidence only on the grounds that the information was unlawfully acquired, or that the information was collected during surveillance that exceeded the authority granted in the FISA warrant. ${ }^{114}$

Once a defendant files a motion to discover, obtain, or suppress FISA evidence, however, the attorney general may file an affidavit claiming that disclosure or an adversary hearing would harm national security. ${ }^{115}$ At that point, the district court must review the application, surveillance order, and other evidence in camera and ex parte to determine the legality of the surveillance. ${ }^{116}$ If the district court

discretion in determining whether to approve a surveillance order than a FISC judge who must approve the order if the procedural requirements have been satisfied.

${ }^{109}$ H.R. REP. No. 95-1283, at 92-93 (1978) (emphasis added).

110) 50 U.S.C. $\$ 1805$ (a) (5) (2000).

111 See id. $\$ 1801(\mathrm{~h})$ (stating that the attorney general shall adopt procedures "to minimize the acquisition and retention, and prohibit the dissemination, of nonpublicly available information concerning unconsenting United States persons consistent with the need of the United States to obtain, produce, and disseminate foreign intelligence information").

\footnotetext{
${ }^{112} I d . \S 1806(\mathrm{~b})$.

$113 \$ 1806(\mathrm{c})$.

$114 \$ 1806(\mathrm{e})$.

${ }^{115} \$ 1806(\mathrm{f})$.

116 Id.
} 
determines that the surveillance was not lawfully authorized, the evidence obtained or derived from the unlawful investigation must be suppressed. ${ }^{17}$ The practical effect of these provisions is that a defendant, even if she is a U.S. citizen, may be prosecuted with evidence collected by electronic surveillance, approved solely on the basis of procedural regularity and documents required by statute, without a showing of probable cause of any criminal wrongdoing, and to which she may never obtain access to at trial-all for the sake of national security.

While Title III was passed by Congress to implement the Court's ruling in Katz and strictly apply the Fourth Amendment warrant requirement to electronic surveillance in law enforcement investigations, FISA was an attempt by Congress to regulate an area about which the Court had remained silent-the executive branch's power to conduct surveillance for foreign intelligence purposes. ${ }^{118}$ Therefore, FISA operates as a procedural framework within the limited foreign intelligence exception to the Fourth Amendment previously recognized by the courts of appeals. ${ }^{119}$ However, Congress did adopt procedural safeguards "necessary to insure that electronic surveillance by the U.S. Government within this country conforms to the fundamental principles of the fourth amendment [sic]."120

While the FISA text does circumscribe surveillance powers, the legislative history indicates that FISA was not intended to satisfy the traditional Fourth Amendment procedures required in law enforcement investigations. In its report on the bill, the House stated that FISA surveillances "are not primarily for the purpose of gathering evidence of a crime. They are to obtain foreign intelligence information, which when it concerns United States persons must be necessary to important national concerns." ${ }^{121}$ The courts reaffirmed this by

${ }_{118}^{117} \$ 1806(\mathrm{~g})$.

18 See United States v. Duggan, 743 F.2d 59, 73 (2d Cir. 1984) ("Congress passed FISA to settle what it believed to be the unresolved question of the applicability of the Fourth Amendment warrant requirement to electronic surveillance for foreign intelligence purposes, and to "remove any doubt as to the lawfulness of such surveillance." (quoting H.R. REP. NO. 95-1283, pt.1, at 25 (1978))).

${ }^{119}$ See supra Part I.C (reviewing the circuit courts' recognition of a foreign intelligence exception to the Fourth Amendment).

${ }^{120}$ S. REP. NO. 95-701, at 13 (1978).

121 H.R. REP. NO. 95-1283, at 36 (1978). 
interpreting FISA in light of the preexisting foreign intelligence exception jurisprudence set forth in cases like Butenko and Truong. ${ }^{122}$

For example, in United States $v$. Megahey, ${ }^{123}$ the government sought to prosecute four defendants, including one U.S. citizen, for conspiring to smuggle firearms and explosives to the Provisional Irish Republican Army for terrorist attacks in Northern Ireland. ${ }^{124}$ The Attorney General authorized use of foreign intelligence information collected during a FISA surveillance against the defendants at trial. ${ }^{125}$ The defendants moved to suppress the evidence as a violation of their Fourth Amendment rights, claiming the surveillance was conducted solely for law enforcement purposes. ${ }^{126}$ After recounting the evolution of the foreign intelligence exception from Keith to Truong, the district court upheld the constitutionality of FISA, ruling that the FISA procedural safeguards implicitly satisfy the Truong primary purpose test. $^{127}$ Turning to the facts of the investigation, the district court determined that since the statutory scope of FISA overlies the constitutional scope of Truong, a valid investigation under one must similarly be valid under the other. ${ }^{128}$ The district court recognized that Congress anticipated the possibility of criminal prosecution through FISA-obtained evidence, but noted that "surveillance under FISA is appropriate only if foreign intelligence surveillance is the Government's primary purpose. ${ }^{129}$ The primary purpose of the investigation was to collect information on the international terrorist group and thus the FISA evidence was usable at trial. ${ }^{190}$

On appeal, the Second Circuit, in United States v. Duggan, ${ }^{131}$ held " $[t]$ he requirement that foreign intelligence information be the primary objective of the surveillance is plain not only from the language

${ }^{122}$ See DYCUS ET AL., supra note 14, at 688 ("Courts have followed Truong and have allowed evidence gathered during FISA surveillance to support a criminal conviction after finding that intelligence was the 'primary' purpose of the surveillance....") (citation omitted); Banks \& Bowman, supra note 14, at 84 ("In each such challenge [by criminal defendants] to date, the lower federal courts have sustained the FISA-based surveillance under the 'primary purpose' test of the Truong decision.").

${ }^{123} 553$ F. Supp. 1180 (E.D.N.Y. 1982), affd sub nom United States v. Duggan, 743 F.2d 59 (2d Cir. 1984).

${ }^{124}$ Id. at 1182.

${ }^{125} I d$. at 1183 .

${ }^{126} I d$. at $1185-86$.

127 Id. at 1189 .

${ }^{128}$ Id.

${ }^{129}$ Id. at $1189-90$.

${ }^{130} I d$. at 1190.

${ }^{131}$ United States v. Duggan, 743 F.2d 59, 73 (2d Cir. 1984). 
of $\S 1802$ (b) but also from the requirements in $\S 1804$ as to what the application must contain." ${ }^{32}$ The Second Circuit affirmed the lower court ruling that "the purpose of the surveillance... was to secure foreign intelligence information and was not... directed towards criminal investigation or the institution of a criminal prosecution."133

Following Duggan, circuit courts continued to follow the primary purpose test in evaluating FISA surveillances. ${ }^{134}$ For example, in 1991, the First Circuit, in United States $v$. Johnson, ${ }^{135}$ found that the primary purpose test was necessary to ensure that FISA was "not to be used as an end-run around the Fourth Amendment's prohibition of warrantless searches." ${ }^{\text {"36 }}$ However, if the FISA surveillance was proper, the court reaffirmed that the fruits of the foreign intelligence surveillance may be used in a subsequent criminal trial. ${ }^{137}$ The First Circuit stated that "[a]lthough evidence obtained under FISA subsequently may be used in criminal prosecutions, the investigation of criminal activity cannot be the primary purpose of the surveillance." 138 Applying this rule, the court found that the primary purpose of the investigation was foreign intelligence and, thus, upheld the use of the FISA evidence at trial.

By contrast, the Ninth Circuit refused to decide the issue of whether a FISA investigation required foreign intelligence to be the "primary purpose" or simply "the purpose" (potentially one of several)

${ }^{132} I d$. at 77 (emphasis added). FISA states that FISC may grant an order approving electronic surveillance "for the purpose of obtaining foreign intelligence information." 50 U.S.C. $\S 1802$ (b) (2000). Similarly, a FISA application requires certification "that the purpose of the surveillance is to obtain foreign intelligence information." Id. \$1804(a)(7)(B). Neither of these two sections cited by the Second Circuit plainly states a primary purpose test. Thus, though it does not explicitly apply Truong to FISA, the Second Circuit in Duggan, by affirming the primary purpose test applied by the district court, read into FISA the heightened foreign intelligence exception standard of Truong.

${ }^{133}$ Duggan, 743 F.2d at 78 (quoting Megahey, 553 F. Supp. at 1190).

194 See, e.g., United States v. Pelton, 835 F.2d 1067, 1076 (4th Cir. 1987) ("We agree with the district court that the "primary purpose of the surveillance, both initially and throughout, was to gather foreign intelligence information.") (citation omitted); United States v. Badia, 827 F.2d 1458, 1464 (11th Cir. 1987) (stating that the investigation "did not have as its purpose the primary objective of investigating a criminal act").

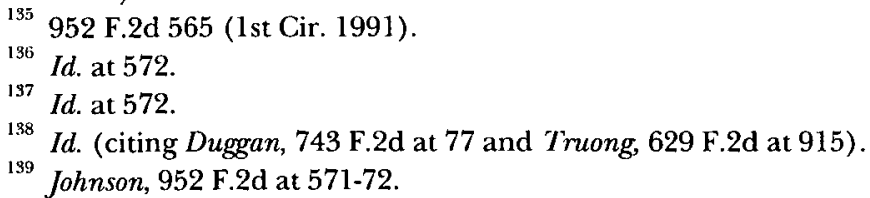


as the law explicitly stated. ${ }^{140}$ The Ninth Circuit wrote, "We refuse to draw too fine a distinction between criminal and intelligence investigations. 'International terrorism,' by definition, requires the investigation of activities that constitute crimes. That the government may later choose to prosecute is irrelevant. FISA contemplates prosecution based on evidence gathered through surveillance. . ."141 "FISA is meant to take into account 'the differences between ordinary criminal investigations to gather evidence of specific crimes and foreign counterintelligence investigations to uncover and monitor clandestine activities."' ${ }^{142}$

The court did not decide the constitutional issue of whether evidence collected during a FISA search, conducted for simply "the purpose" of gathering foreign intelligence information, would be admissible under the Fourth Amendment. Put another way, the Ninth Circuit passed on the question of whether Truong is the constitutional standard in a criminal prosecution. Before the circuit courts could reach consensus on the question, the Attorney General stepped into the debate.

\section{The 1995 Attorney General Procedures}

In 1995, Attorney General Janet Reno adopted comprehensive procedures governing the interaction between law enforcement and foreign intelligence investigations. ${ }^{143}$ The 1995 Procedures effectively ended the legal debate by explicitly adopting the primary purpose test and the operational distinctions set forth in Truong. ${ }^{144}$ Following the Fourth Circuit's reasoning, the 1995 Procedures erected a wall with the Criminal Division on one side and the FBI and the Office of

${ }^{140}$ See United States v. Sarkissian, 841 F.2d 959, 964 (9th Cir. 1988) ("Regardless of whether the test is one of purpose or primary purpose, our review of the government's FISA materials convinces us that it is met in this case.").

${ }^{14 !} I d$. at 965 (quoting 50 U.S.C. $\$ 1801$ (c) (1) (2000)).

142 Id. (quoting S. REP. No. 95-701, at 11 (1978), reprinted in 1978 U.S.C.C.A.N. 3973, 3983).

${ }_{143}$ See Memorandum from Janet Reno, Attorney General, to the Assistant Attorney General of the Criminal Division, Director of the FBI, Counsel for Intelligence Policy, and United States Attorneys (July 19, 1995) [hereinafter The 1995 Procedures] (outlining "Procedures for Contacts Between the FBI and the Criminal Division Concerning Foreign Intelligence and Foreign Counterintelligence Investigations"), http://www.fas.org/irp/agency/doj/fisa/1995procs.html.

${ }^{144}$ See 629 F.2d at 916 ("[E]ven these actors receive the protection of the warrant requirement if the government is primarily attempting to put together a criminal prosecution."); see also supra text accompanying notes 57-69 (discussing the Troung decision). 
Intelligence Policy and Review (OIPR) (the government lawyers who stand before the FISC) on the other. ${ }^{145}$ The rationale behind the separation was to protect the integrity of FISA investigations by ensuring that they remained primarily for intelligence purposes. ${ }^{146}$ The 1995 Procedures provided that the FBI and OIPR inform the Criminal Division when an investigation reasonably indicated "that a significant federal crime has been, is being, or may be committed."147 The FBI and OIPR were required to give the Criminal Division the facts and circumstances supporting their belief that criminal activity was involved. ${ }^{148}$ If the Criminal Division believed law enforcement interests were implicated, it could give "guidance to the FBI aimed at preserving the option of a criminal prosecution." 49 The 1995 Procedures explicitly stated that:

The Criminal Division shall not, however, instruct the FBI on the operation, continuation, or expansion of FISA electronic surveillance or physical searches. Additionally, the FBI and Criminal Division should ensure that advice intended to preserve the option of a criminal prosecution does not inadvertently result in either the fact or the appearance of the Criminal Division's directing or controlling the [foreign intelligence] or [foreign counterintelligence] investigation toward law enforcement objectives.

To verify the separation throughout a FISA investigation in which the Criminal Division was participating, the FBI was directed to maintain a $\log$ of all contacts between the two divisions, ${ }^{151}$ and the OIPR was required to keep the FISC apprised of the nature of the Criminal Division's participation in any renewal FISA applications. ${ }^{152}$

Following the adoption of the 1995 Procedures, it would seem the debate over the constitutionality of the foreign intelligence exception

${ }^{145}$ See The 1995 Procedures, supra note 143, A(1) (regulating contacts between the Criminal Division of the Justice Department, the FBI, and the OIPR during foreign intelligence and counterintelligence investigations). The Truong court affirmed that the purpose of an investigation can be determined by which division within the Justice Department was playing the lead role. 629 F.2d at 913-16. Thus, when the Criminal Division of the Justice Department took over a central role in the investigation, its focus became primarily criminal in nature. Id. at 916 .

${ }^{146}$ See The 1995 Procedures, supra note 143 ("The purpose of these procedures is to ensure that [foreign intelligence] and [foreign counterintelligence] investigations are conducted lawfully.").

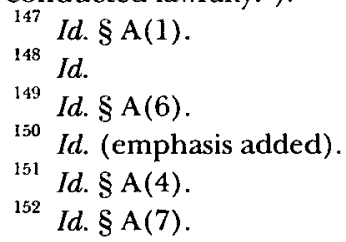


was finally resolved. By implementing the primary purpose doctrine, the Justice Department clearly defined the constitutionally murky boundaries between intelligence and law enforcement. However, without a definitive Supreme Court ruling or at least a consensus among the circuits, the boundaries were merely internal guidelines of one executive administration, which could easily be altered by a change in circumstances, a change in administration, or both.

\section{REINTERPRETATION OF FISA AFTER SEPTEMBER 11}

\section{A. The Patriot Act's Amendments to FISA}

The terrorist attacks on the morning of September 11, 2001, were the most horrific foreign strikes to ever occur on U.S. soil. The following day the Department of Justice began working “"on a package of authorities" "153 to provide law enforcement with, in the words of Attorney General John Ashcroft, "'all that is necessary ... within the bounds of the Constitution, to discharge the obligation to fight this war against terror." ${ }^{\prime 154}$ A crisis mentality permeated the nation's capital, which some administration officials saw as an opportunity to push through previously rejected and long-stalled legal changes aimed at strengthening law enforcement at the expense of civil liberties. Attorney General Ashcroft challenged Congress to act quickly and bypass the usual legislative process, enacting the new legislation within a week. ${ }^{155}$

With respect to FISA, the "Bush administration believed those barriers [between law enforcement and foreign intelligence] were getting in the way of uncovering terrorist cells operating here and abroad." ${ }^{156}$ As an illustration of this proposition, the Administration cited the case of Zacarias Moussaoui, the so-called "twentieth

${ }^{153}$ Robert O'Harrow, Jr., Six Weeks in Autumn, WASH. Posr, Oct. 27, 2002, (Magazine), at 9 (quoting Assistant Attorney General Viet Dinh).

${ }^{154}$ Id. (quoting Attorney General Ashcroft).

${ }^{155}$ See id. at 20 ("'I think it is time for us to be productive on behalf of the American people,' said the attorney general. 'Talk won't prevent terrorism,' Ashcroft said, adding that he was 'deeply concerned about the rather slow pace' of the legislation.”); see also 147 CONG. REC. S10,991 (daily ed. Oct. 25, 2001) (statement of Sen. Leahy) ("We expedited the legislative process in the Judiciary Committee to consider the Administration's proposals. In daily news conferences prior to the original passage of the USA [Patriot] Act, the Attorney General referred to the need for such prompt consideration.").

${ }^{156}$ O'Harrow, supra note 153, at 11. 
hijacker," 157 whom the Administration claimed was under suspicion by FBI law enforcement agents. ${ }^{158}$ The government claimed a FISA warrant was never sought to search his computer because the primary purpose test had made OIPR overly cautious about seeking FISA surveillance against a suspect first identified by law enforcement. ${ }^{159}$

As a result of this perceived deficiency, one of the changes the Justice Department proposed was to alter the FISA purpose requirement from foreign intelligence must be "the purpose" of an investigation, to simply " $a$ purpose." ${ }^{\text {"60 }}$ However, congressional members from both parties balked at the suggestion, fearing that " $[\mathrm{g}]$ iving criminal investigators unchecked access to FISA powers could break down constitutional safeguards against unreasonable searches and seizures, leading to abuses against U.S. citizens." ${ }^{161}$ In the end, the two sides compromised and section 218 of the Patriot Act amended the language of FISA $\$ 1804(\mathrm{a})(7)(\mathrm{B})$ to require that "a significant purpose of the surveillance is to obtain foreign intelligence information." 162

In accepting the compromise, however, Senator Leahy, the Chairman of the Judiciary Committee and a cosponsor of the bill, noted that " $[n]$ o matter what statutory change is made even the [Justice] Department concedes that the court may impose a constitutional requirement of 'primary purpose' based on the appellate court decisions upholding FISA against constitutional challenges over the past 20 years." ${ }^{163}$ Regardless of any constitutional

${ }^{157}$ Edward Lazarus, FindLaw Forum: Why the Case of Zacarias Moussaoui Presents a Conundrum for Death Penalty Abolitionists (April 2, 2002), at http://us.cnn.com/2002/ LAW/04/columns/fl.lazarus.moussaoui.04.04/ (discussing the prosecution of Moussaoui as the "twentieth hijacker" of the September 11, 2001 attacks).

${ }_{158}$ See DYCUS ET AL., supra note 14, at 689-90 (stating that an FBI request to open a criminal investigation of Moussaoui was denied because it might thwart a later FISA request); see also Charles Lane, In Terror War, 2nd Track for Suspects; Those Designated 'Combatants' Lose Legal Protections, WASH. POST, Dec. 1, 2002, at A1 (reporting that administration officials attributed the wall between law enforcement and counterintelligence for the failure to seek permission to search Moussaoui's computer preSeptember 11-a crucial missed opportunity which could have prevented the attacks).

${ }^{159}$ DYCUS ET AL., supra note 14 , at 689-90.

160

161 Id.

O'Harrow, supra note 153, at 18.

162 50 U.S.C.A. $§ 1804(\mathrm{a})(7)$ (B) (West Supp. 2002) (emphasis added). The companion provision covering physical searches was also amended to "a significant purpose." Id. § 1823(a)(7)(B); see also Patriot Act, Pub. L. No. 107-56, § 218, 115 Stat. 291 (2001) (adding the "significant purpose" language).

${ }^{163} 147$ CONG. ReC. S11,003 (daily ed. Oct. 25, 2001) (statement of Sen. Leahy). 
doubts of Congress, the law passed overwhelmingly. Six weeks after the attacks occurred, President Bush signed the bill into law. ${ }^{164}$

\section{B. The 2002 Attorney General Procedures}

Shortly after passage of the Patriot Act, Attorney General Ashcroft implemented it by replacing the 1995 Procedures $^{165}$ with new guidelines mandating closer interaction between law enforcement and intelligence agents. The Attorney General adopted new procedures for FISA investigations conducted "primarily for a law enforcement purpose" but with a "significant foreign intelligence purpose" as well. ${ }^{166}$ The 2002 Procedures state that the "Criminal Division and OIPR shall have access to all information developed in full field [foreign intelligence] and [foreign counterintelligence] investigations." ${ }^{167}$ Furthermore, the 2002 Procedures require the FBI, Criminal Division, and OIPR to "consult with one another ... on all issues necessary to the ability of the United States to investigate or protect against foreign attack, sabotage, terrorism, and clandestine intelligence activities, including protection against the foregoing through criminal investigation and prosecution." 168 Most importantly, the parties are required to consult on issues including "the initiation, operation, continuation, or expansion of FISA searches or surveillance."169

The 2002 Procedures represented a dramatic shift from the prior guidelines, which required the Criminal Division to avoid even the appearance of directing or controlling a FISA investigation. ${ }^{170}$ Now, a FISA

${ }^{164}$ For a discussion of the effect of the Patriot Act on investigative techniques, see Rackow, supra note 14, at 1680-83.

${ }^{165}$ See supra text accompanying notes 143-52 (discussing the 1995 Procedures in greater detail).

${ }_{166}$ Memorandum from John Ashcroft, Attorney General, to the Assistant Attorney General of the Criminal Division, Director of the FBI, Counsel for Intelligence Policy and United States Attorneys $\S$ I (March 6, 2002) [hereinafter the 2002 Procedures] (outlining "Intelligence Sharing Procedures for Foreign Intelligence and Foreign Counterintelligence Investigations Conducted by the FBI"), http://www.fas.org/irp/ agency/doj/fisa/ag030602.html.

${ }^{167}$ Id. $\S \mathrm{II}(\mathrm{A})$ (emphasis added).

168 Id. $\$ \mathrm{II}(\mathrm{B})$.

169 Id.

170 See The 1995 Procedures, supra note 143, A(6) ("[T]he FBI and Criminal Division should ensure that advice intended to preserve the option of a criminal prosecution does not inadvertently result in either the fact or the appearance of the Criminal Division's directing or controlling the [foreign intelligence] or [foreign 
investigation, conducted primarily for law enforcement purposes but with a significant foreign intelligence component, could be initiated, directed and controlled by law enforcement officials, rather than intelligence agents. However, both the 2002 Procedures and the Patriot Act had yet to face judicial scrutiny.

\section{The FISC Opinion}

In May 2002, the government submitted the 2002 Procedures to the FISC for en banc review. ${ }^{171}$ The FISC previously had adopted the 1995 Procedures as proper minimization procedures and "incorporated them in all applicable orders and warrants granted since then." ${ }^{172}$ In this case, the government argued that the 2002 Procedures superseded the prior ones and therefore, requested that the FISC incorporate the new guidelines into all future orders and warrants. ${ }^{173}$ The FISC interpreted the issue before it as a straightforward analysis of whether the 2002 Procedures satisfied FISA's minimization procedures requirement as stated in $\S 1801(\mathrm{~h}),{ }^{174}$ rather than as a constitutional question of whether FISA, as amended by the Patriot Act, may be used for primarily law enforcement purposes. ${ }^{17}$

The FISC began its analysis noting that investigative powers under FISA are significantly broader than those granted to the government under Title III. ${ }^{176}$ Specifically, the FISC noted seven distinctions between a FISA search and a standard criminal search as highlighted in Table $1 .{ }^{177}$

counterintelligence] investigation toward law enforcement objectives."), at http:// www.fas.org/irp/agency/doj/fisa/ag030602.html.

${ }^{171}$ In re All Matters Submitted to the Foreign Intelligence Surveillance Court, 218 F. Supp. 2d 611 (Foreign Intelligence Surveillance Ct. 2002) [hereinafter FISC Opinion]. The FISC Opinion was only the second one ever publicly disclosed.

${ }^{172} I d$. at 616 .

${ }^{173} \mathrm{Id}$.

${ }^{174}$ See 50 U.S.C. $\$ 1801(\mathrm{~h})$ (2000) (requiring the attorney general to adopt procedures to minimize dissemination of non-public available information concerning unconsenting U.S. persons). The companion provision covering minimization procedures for physical searches is $i d$. $\$ 1821(4)$.

\footnotetext{
218 F. Supp. $2 d$ at 614.

${ }^{176} I d$. at 616.

${ }^{177} I d$. at 617.
} 


\section{Table 1: Comparison Between Powers Granted Through FISA and Title III}

\begin{tabular}{|c|c|c|}
\hline & FISA & Title III \\
\hline Probable Cause & $\begin{array}{l}\text { Of being a foreign power or an } \\
\text { agent of a foreign power }{ }^{178}\end{array}$ & Of criminal wrongdoing $^{1 / 79}$ \\
\hline $\begin{array}{l}\text { Facilities } \\
\text { Covered }\end{array}$ & $\begin{array}{l}\text { Facility targeted must be used by } \\
\text { the foreign power or agent of a } \\
\text { foreign power; no need to show in } \\
\text { furtherance of activities }\end{array}$ & $\begin{array}{l}\text { Facility targeted must be used in } \\
\text { furtherance of criminal activity }{ }^{11}\end{array}$ \\
\hline Notice & $\begin{array}{l}\text { Surveillance/searches conducted } \\
\text { without notice to target unless } \\
\text { prosecuted }^{182}\end{array}$ & $\begin{array}{l}\text { Must provide notice to target of } \\
\text { surveillance/search }\end{array}$ \\
\hline Duration & $\begin{array}{l}\text { Authorized for } 90 \text { days, may be up } \\
\text { to a year }{ }^{154}\end{array}$ & $\begin{array}{l}\text { Authorized for no longer than } 30 \\
\text { days }{ }^{185}\end{array}$ \\
\hline Usage & $\begin{array}{l}\text { May use surveillance for both } \\
\text { foreign intelligence and as } \\
\text { evidence of crime }\end{array}$ & $\begin{array}{l}\text { May only be used as evidence of a } \\
\text { crime }{ }^{187}\end{array}$ \\
\hline Minimization & $\begin{array}{l}\text { May collect data by automatic } \\
\text { recording and minimize after the } \\
\text { fact }^{188}\end{array}$ & $\begin{array}{l}\text { Requires minimization during } \\
\text { surveillance } e^{189}\end{array}$ \\
\hline At Trial & $\begin{array}{l}\text { Not subject to discovery; ex parte, } \\
\text { in camera review by court }\end{array}$ & $\begin{array}{l}\text { Must provide defendant with } \\
\text { application and order, and judge } \\
\text { may allow defendant to inspect } \\
\text { intercepts }{ }^{191}\end{array}$ \\
\hline
\end{tabular}

The FISC reasoned that FISA gives the government unusually broad power to investigate and retain information for the purpose of collecting foreign intelligence against U.S. persons. ${ }^{192}$ By extending those powers to law enforcement, the 2002 Procedures give the Criminal Division "every legal advantage conceived by Congress to be

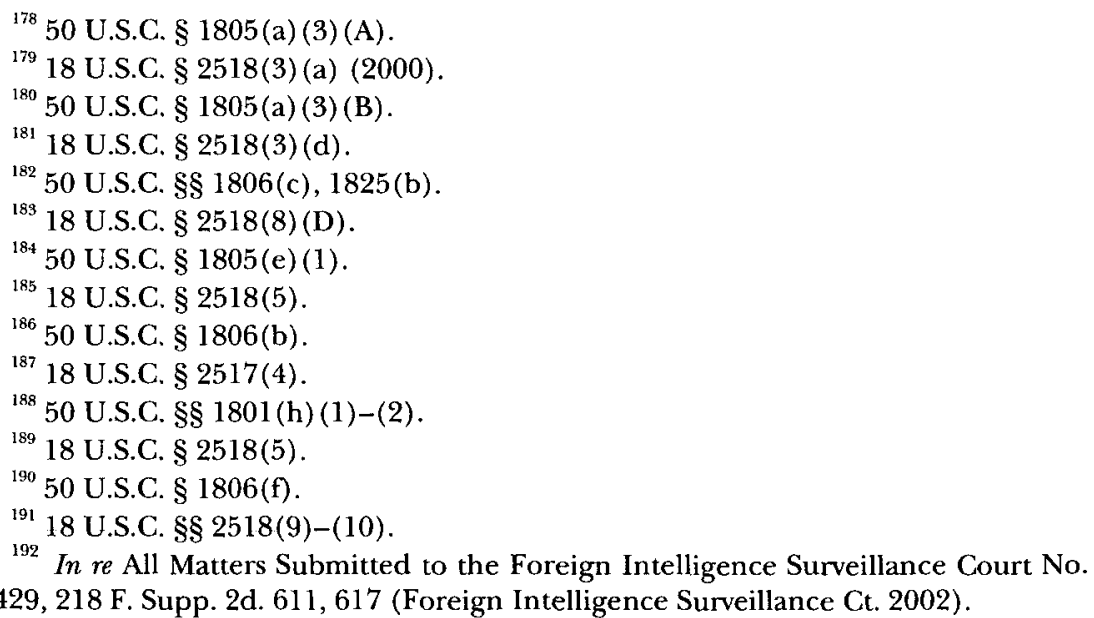

02-429, 218 F. Supp. 2d. 61 1, 617 (Foreign Intelligence Surveillance Ct. 2002). 
used by U.S. intelligence agencies to collect foreign intelligence information." ${ }^{193}$ Therefore, the FISC concluded:

[t]he 2002 procedures appear to be designed to amend the law and substitute the FISA for Title III electronic surveillances and Rule 41 searches. This may be because the government is unable to meet the substantive requirements of these law enforcement tools, or because their administrative burdens are too onerous. In either case, the FISA's definition of minimization procedures has not changed, and [the 2002] procedures cannot be used by the government to amend the Act in ways Congress has not. ${ }^{194}$

The issue before the FISC, therefore, was whether the 2002 Procedures exceeded the bounds of FISA.

The FISC noted that pursuant to $\$ 1801(\mathrm{~h})$, minimization procedures must be "consistent with the need of the United States to "obtain, produce, and disseminate foreign intelligence information." Thus, the FISC concluded that "[i]f direction of counterintelligence cases involving the use of highly intrusive FISA surveillances and searches by criminal prosecutors is necessary to obtain and produce foreign intelligence information, it is yet to be explained to the court."196

To ensure the 2002 Procedures fell within their statutory purpose, the FISC held that the FBI, the Criminal Division, and OIPR may consult and coordinate with each other, but "law enforcement officials shall not make recommendations to intelligence officials concerning the initiation, operation, continuation or expansion of FISA searches or surveillances." 197 Furthermore, the FISC held that the parties must ensure that "law enforcement officials do not direct or control the use of the FISA procedures to enhance criminal prosecution, and that advice... does not inadvertently result in the Criminal Division's directing or controlling the investigation using FISA searches and surveillances toward law enforcement objectives." 198

Thus, the FISC unanimously modified the 2002 Procedures by eliminating those FISA investigations directed for primarily law enforcement purposes without even acknowledging the Patriot Act's effect on FISA or deciding the constitutional issue of a significant

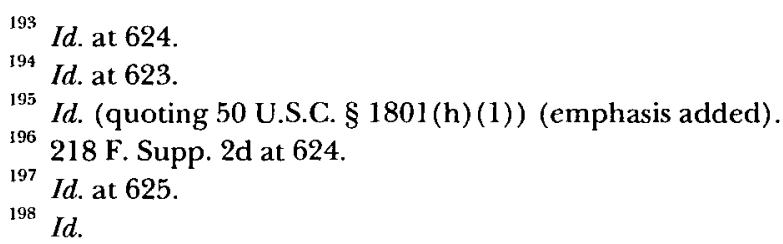


purpose. The ruling was a remarkable blow to the government by a court, which up until this point, had done little more than rubber stamp government foreign intelligence activities. While civil libertarians applauded the decision, their celebration would be short lived.

\section{The Government's Appeal}

Rather than appeal the FISC Opinion, the government brought an application for surveillance against a U.S. person under the 2002 Procedures framework. ${ }^{199}$ The FISC authorized the surveillance, but imposed the same limitations on the investigation as it laid out in its FISC Opinion to ensure law enforcement officials did not direct or control FISA investigations for criminal prosecution purposes. ${ }^{200}$ The government, for the first time in the twenty-four year history of FISA, appealed to the FISCR.

In its brief, the government made three principal arguments for why FISA surveillances may be used for primarily law enforcement purposes. First, the Justice Department argued that the courts had misapplied the pre-Patriot Act FISA over the past twenty years by reading into the statutory language the need for foreign intelligence to be the primary purpose of an investigation. ${ }^{201}$ Second, even if the primary purpose test was correct, the Patriot Act amended that language to "a significant purpose," which allows for a primary purpose that is not foreign intelligence. ${ }^{202}$ Third, the primary purpose test is not constitutionally required, and therefore the Patriot Act's amended language is valid. ${ }^{203}$ Therefore, the government argued that the FISC erred when it rejected the "direction or control" provisions of the 2002 Procedures. ${ }^{204}$

${ }^{199}$ Brief for the United States, In re All Matters Submitted to the Foreign Intelligence Surveillance Court, 218 F. Supp. 2d 611 (Foreign Intelligence Surveillance Ct. 2002) (No. 02-001) [hereinafter Government's Brief], at http://www.fas.org/irp/ agency/doj/fisa/082102appeal.html.

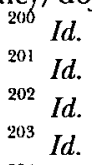

${ }^{204} I d$. In response to the FISC's statutory argument, the government argued the FISC had misapplied the minimization requirements of the Act. The government claimed the minimization requirements only deal with information "not otherwise subject to collection under FISA," while the 2002 Procedures governed only coordination among agencies regarding foreign intelligence information already sanctioned by FISA. Id. 
The government's brief noted that the original intent of FISA was to gather foreign intelligence information, which may include evidence of criminal activity. ${ }^{205}$ First, the government argued that foreign intelligence investigations conducted primarily for law enforcement purposes are within the scope of FISA. ${ }^{206}$ The statute does not "limit how the government may use the information" it collects and "[p]rosecution is often a most effective means of protecting national security." ${ }^{207}$ Thus, in the opinion of the Justice Department, for the past twenty years the courts had misinterpreted FISA by distinguishing between law enforcement and foreign intelligence rather than between actions taken to protect national security and those that did not. ${ }^{208}$ The government argued the "primary purpose" cases were decided wrongly because "the government never advanced the idea that prosecution may be used to protect national security, or that FISA may be used to obtain evidence for such a prosecution." 209

Second, even if the purpose distinction and the primary purpose test were considered the correct reading of the original FISA language, the Patriot Act amended the requirement to "a significant purpose."210 Thus, the government argued, so long as foreign intelligence remained a significant purpose, the primary purpose could be criminal prosecution. ${ }^{21}$ Furthermore, because the term "significant" is neither a relative nor a comparative term, the government argued that the courts do not need to investigate or review the role of law enforcement in the investigation. ${ }^{212}$ "Indeed, where law enforcement officials seek evidence to prosecute a spy or terrorist, intelligence officials will always (or almost always) have at least a significant purpose to obtain the same information." ${ }^{213}$ As a result, the government concluded the "direction or control"

${ }_{206}^{205} I d$

${ }^{207}$ Id.; see also H.R. REP. NO. 95-1283, pt.1, at 49 (1978) ("Obviously, use of 'foreign intelligence information' as evidence in a criminal trial is one way the Government can lawfully protect against clandestine intelligence activities, sabotage, and international terrorism.").

208 See Government's Brief, supra note 199 at II.A.5 (arguing that law enforcement operations should not be considered per se improper under FISA).

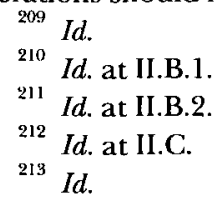


restriction imposed by the FISC Opinion has no support in the text of the law or in any interpretation of it. ${ }^{214}$

Finally, the government claimed the primary purpose test is more demanding than that which the Fourth Amendment requires, and thus the Patriot Act's significant purpose test is constitutional. ${ }^{215}$ The Department of Justice argued that while Keith held that intelligencegathering investigations involving domestic organizations implicate traditional Fourth Amendment requirements, more flexible standards could apply to intelligence investigations involving foreign powers. ${ }^{216}$ Because FISA necessarily involves foreign threats, the government reaffirmed the argument that it relies on the president's inherent powers as commander in chief and as the sole organ in foreign affairs. ${ }^{217}$ Foreign affairs is a sphere where the president "exercises very delicate, plenary and exclusive power, and in which judicial intervention is rarely proper." ${ }^{218}$

The brief claimed that "the nature of the threat, not the nature of the government's response to the threat ... determines the constitutionality of national security surveillance." ${ }^{219}$ The government concluded so long as the investigation is directed towards a foreign power or an agent of a foreign power, the full Fourth Amendment strictures do not apply, regardless of whether law enforcement is its primary purpose. ${ }^{220}$ "Nothing in Keith suggests that the availability of more relaxed constitutional standards for a search or surveillance depends on the absence of a law enforcement purpose." ${ }^{221}$ While not adopting the government's reasoning, the FISCR upheld the government's position.

\section{E. The FISCR Reversal}

In its first-ever ruling, the FISCR reversed the FISC decision, claiming it lacked both statutory and constitutional foundation. ${ }^{222}$ The FISCR addressed the government's first argument by noting that

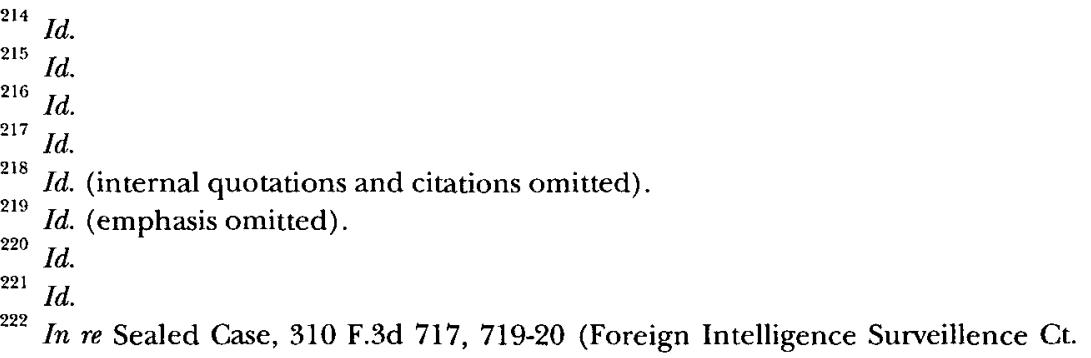
Rev. 2002) (per curiam), cert. denied, 123 S. Ct. 1615 (2003). 
many of the statutory definitions in FISA, including "agent of a foreign power" or "international terrorism," may include elements of criminal activity, which the FISCR broadly defined as "foreign intelligence crimes." ${ }^{\text {223 }}$ The court held "it is virtually impossible to read the 1978 FISA to exclude from its purpose the prosecution of foreign intelligence crimes, most importantly because... the definition of an agent of a foreign power-if he or she is a U.S. person-is grounded on criminal conduct." ${ }^{224}$ Thus, the FISCR concluded that FISA never contemplated that a court ever would inquire into the government's purpose at all or require a non-law enforcement focus. ${ }^{225}$

The FISCR noted that the legislative history supported the government's argument that Congress specifically intended for the use of law enforcement to protect against foreign intelligence threats. ${ }^{226}$ Since the term "foreign intelligence information" includes foreign intelligence crimes, the purpose requirement in FISA was to prevent the use of FISA warrants for gathering non-foreign intelligence information and not to restrict the government's use of proper foreign intelligence information to criminally prosecute. ${ }^{227}$ The court agreed with the government that "prosecution is one way to combat foreign intelligence crimes." 228

Finally, the court held that the primary purpose cases, like Duggan and Johnson, never tied the primary purpose test to the language in the statute. ${ }^{229}$ The FISCR observed Duggan "never explained why it apparently read foreign intelligence information to exclude evidence of crimes-endorsing the district court's implied dichotomy-when the statute's definitions of foreign intelligence and foreign agent are actually cast in terms of criminal conduct." ${ }^{230}$ The Court recognized that the government's principal objective is to stop the agent's activities by

${ }^{223} I d$. at 723 . The $\$ 1801$ (b) (2) (A) definition of an "agent of a foreign power" includes a person who "knowingly engages in clandestine intelligence gathering activities ... [which] may involve a violation of the criminal statutes of the United States." 50 U.S.C. $\$ 1801$ (b)(2) (A). \$ 1801 (c)(1) defines international terrorism as activities that "involve violent acts or acts dangerous to human life that are a violation of the criminal laws of the United States." $\$ 1801(\mathrm{c})(1)$.

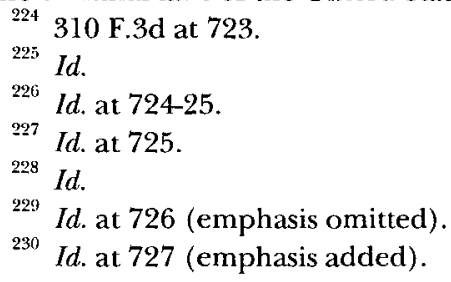


"any means, but if one considers the actual ways in which the government would foil espionage or terrorism it becomes apparent that criminal prosecution analytically cannot be placed easily in a separate response category." ${ }^{231}$

While the original FISA language did not contemplate a distinction between law enforcement and foreign intelligence purposes, the Patriot Act's significant purpose test certainly does. ${ }^{232}$ Therefore, the FISCR held that the government's argument based on the pre-Patriot FISA language was no longer valid, since the dichotomy between law enforcement and foreign intelligence was now relevant, although under the less stringent significant purpose test. ${ }^{233}$

In applying the Patriot Act, the FISCR held that while law enforcement objectives may be the primary purpose, the objectives must be directed towards foreign intelligence crime, rather than ordinary crime. ${ }^{234}$ The Court rejected the government's argument that "prosecutions of non-foreign intelligence crimes are consistent with a purpose of gaining foreign intelligence information so long as the government's objective is to stop espionage or terrorism by putting an agent of a foreign power in prison." ${ }^{, 335}$ The FISCR reasoned that such a use would transgress the meaning and purpose of FISA, which intended the certification requirement "to prevent the government from targeting a foreign agent when its true purpose was to gain non-foreign intelligence information-such as evidence of ordinary crimes or scandals." ${ }^{236}$

Thus, even if the government had a significant foreign intelligence purpose, a FISA application should be denied if its primary purpose was criminal prosecution for non-foreign intelligence crimes. ${ }^{237}$ The court also recognized, however, that "ordinary crimes might be inextricably intertwined with foreign intelligence crimes"-such as international terrorists who finance their terrorist

231 Id

232 Id. at 735.

233 Id. The FISCR noted that Congress, while adopting the law enforcement/foreign intelligence dichotomy in the Patriot Act's significant purpose test, did not amend the term "foreign intelligence information" which the FISCR already stated includes foreign intelligence crimes. Id. However, the FISCR opinion reasoned around this "analytic conundrum" by reading the pre-Patriot FISA language as excluding FISA investigations with the "sole objective of criminal prosecution." Id.

${ }^{234} I d$. at 736 .

235 Id. at 735-36 (emphasis omitted).

236i Id. at 736 (internal quotations omitted).

237 Id. 
activities by robbing banks-that would then make FISA applicable. ${ }^{238}$ Under such a scenario, the FISCR held FISA could be used to investigate the bank robbery "as evidence of the terrorist act itself" but not to "investigate wholly unrelated ordinary crimes."

Turning to the constitutionality of the Patriot Act, the FISCR did not decide whether a FISA warrant satisfied the Fourth Amendment warrant requirements, but rather, limited its analysis to whether FISA searches under the significant purpose test are constitutionally reasonable. ${ }^{240}$

To answer this question, the FISCR analyzed Truong and identified what it considered to be the false premise upon which that opinion was based-specifically, that once an investigation became criminal in nature, "its foreign policy concerns recede. ${ }^{241}$ The court noted that in the field of counterintelligence, intelligence and law enforcement purposes are intertwined. ${ }^{242}$ Thus, the line Truong drew between foreign intelligence and law enforcement was "inherently unstable, unrealistic and confusing." ${ }^{243}$ Furthermore, such line drawing led to "dangerous confusion" and "perverse organizational incentives" as walls were constructed between intelligence and law enforcement divisions, discouraging cooperation necessary to ensure national security. ${ }^{244}$ While national security concerns cannot abrogate Fourth Amendment requirements, the court held that Truong misinterpreted both the government's interest and the Supreme Court's ruling in Keith, which suggested that a more relaxed warrant procedure may be appropriate in cases involving national security than in cases involving ordinary crime. ${ }^{245}$ Thus, the FISCR concluded the distinction that the Supreme Court had suggested in Keith was the same as stated by the original FISA language-a distinction between ordinary crimes and foreign intelligence crimes. ${ }^{246}$ In the case of foreign intelligence crimes, the government's overwhelming interest is to prevent the immediate threat through whatever means available, including

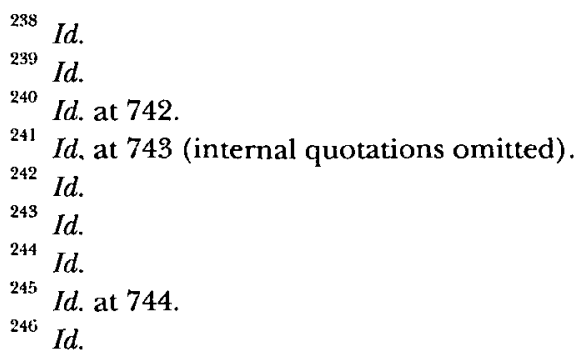


criminal prosecution. ${ }^{247}$ The court concluded "[p]unishment of the terrorist or espionage agent is really a secondary objective; indeed, punishment of a terrorist is often a moot point."248

Finally, the court held FISA is constitutional under the Supreme Court's Fourth Amendment "special needs" doctrine, which upholds "warrantless and even suspicionless searches that are designed to serve the government's 'special needs, beyond the normal need for law enforcement." ${ }^{249}$ The FISCR noted that the Supreme Court rejected suspicionless searches when the primary purpose was ordinary law enforcement. $^{250}$ The "special needs" cases, however, permit the government to pursue a special programmatic purpose, such as public school discipline, road safety, or immigration control, without regard to the subjective intent of the officers. ${ }^{253}$ Thus, the Fourth Amendment analysis does not consider whether an officer's subjective purpose is law enforcement provided there is a non-law enforcement special need.

Applying this "special needs" analysis, the FISCR concluded that "FISA's general programmatic purpose, to protect the nation against terrorists and espionage threats directed by foreign powers ... [is] distinguishable from ordinary crime control." ${ }^{252}$ Because protection against foreign threats of terrorism is its main purpose, FISA falls within the Fourth Amendment's "special needs" doctrine. ${ }^{253}$ As a result, the FISCR found searches and surveillance conducted without the normal Fourth Amendment protections of a warrant and judicial authorization and review to be constitutionally reasonable. ${ }^{254}$

247 Id

248 Id. at $744-45$.

249 Id. at 745 (quoting Vernonia Sch. Dist. v. Acton, 515 U.S. 646, 653 (1995)); see also Vernonia, 515 U.S. at 664-65 (upholding suspicionless drug testing of student athletes); Mich. Dep't of State Police v. Sitz, 496 U.S. 444, 455 (1990) (holding roadblocks to stop drunk drivers constitutional); United States v. Martinez-Fuerte, 428 U.S. 543, 566-67 (1976) (permitting suspicionless border patrol checkpoint stops as reasonable under the Fourth Amendment).

${ }^{250} 310$ F.3d at 745 (quoting City of Indianapolis v. Edmond, 531 U.S. 32, 41-42 (2000)); see also Ferguson v. City of Charleston, 532 U.S. 67, 82-84 (2001) (rejecting drug testing of obstetrics patients where "the immediate objective of the searches was to generate evidence for law enforcement purposes").

251310 F.3d at 745; see also Whren v. United States, 517 U.S. 806, 813 (1996) (holding the subjective intent of a police officer is irrelevant in a probable cause analysis).

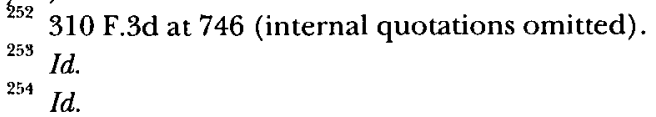




\section{EXAMINING THE FISCR OPINION}

\section{A. Statutory Analysis: The Flawed Distinction of Foreign Intelligence Crimes}

The FISCR first stated that the pre-Patriot Act FISA language clearly contemplated the criminal prosecution of foreign intelligence crimes, which it tried to distinguish from ordinary crimes. ${ }^{255}$ The FISCR's definition of "foreign intelligence crimes" was based on the statutory definitions of "agent of a foreign power," "international terrorism," and "sabotage." 56 This distinction, however, is anything but apparent in these statutory definitions.

The statutory language does not clearly delineate between foreign intelligence crimes and other criminal violations. Specifically, $\S 1801$ (b) (2) (A) of Title III states that an "agent of a foreign power" includes any person who "knowingly engages in clandestine intelligence gathering activities[,] . . which activities involve or may involve a violation of the criminal statutes of the United States." ${ }^{257}$ The statutory definition leaves open the possibility that a U.S. citizen may be involved in clandestine intelligence activities that do not involve criminal conduct at all. Furthermore, while the statute clearly contemplates crimes like espionage, any violation of the criminal statutes, no matter how minor, would fall within its definition.

Similarly, the term "international terrorism" is defined as "violent acts or acts dangerous to human life that are a violation of the criminal laws of the United States... or that would be a criminal violation if committed within the jurisdiction of the United States" ${ }^{\text {"58 }}$ and "occur totally outside the United States or transcend national boundaries." 259 Like the definition of an "agent of a foreign power," this definition does not apply only to crimes committed in the United States.

Finally, the term "foreign intelligence information" does not have any criminal conduct component to it at all. It is broadly defined as information necessary for the United States to protect against "actual or potential attack... or international terrorism." ${ }^{260}$ Criminal conduct is not required.

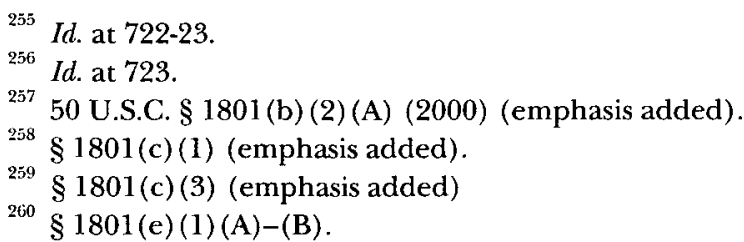


The FISCR simply mischaracterized the statute when it stated that a FISA investigation is necessarily "grounded on criminal conduct." Even if criminal conduct is involved, FISA does not distinguish between types of substantive crimes, but rather allows for any criminal violation to qualify as an agent of a foreign power and any violent or life threatening crime for purposes of defining international terrorism. It is hard to see any statutory basis for the Court's foreign intelligence crime/ordinary crime distinction.

The FISCR wrote "it is virtually impossible to read the 1978 FISA to exclude from its purpose the prosecution of foreign intelligence crimes. ${ }^{262}$ But the court's interpretation is at odds with $\S 1806$ (b), which expressly states that no FISA information "shall be disclosed for law enforcement purposes" without prior approval. ${ }^{263}$ Further, the statute requires that FISA information "may only be used in a criminal proceeding with the advance authorization of the Attorney General."264 Clearly, the plain language and structure of the statute set up the dichotomy between foreign intelligence and law enforcement. If, as the FISCR claimed, the criminal prosecution of foreign intelligence crimes was contemplated by FISA, why would the heightened disclosure requirement of $\S 1806$ (b) be warranted? Why would the disclosure requirement explicitly distinguish between foreign intelligence crimes and ordinary crimes, requiring nothing for the former, but heightened approval for the latter?

The legislative history further reveals the deficiency in the FISCR reasoning. While Congress clearly anticipated the use of FISA information in subsequent criminal trials, FISA surveillances "are not primarily for the purpose of gathering evidence of a crime. They are to obtain foreign intelligence information, which when it concerns United States persons must be necessary to important national concerns." ${ }^{265}$ It was Congress that created the foreign intelligence/law enforcement dichotomy by writing it into the statute itself.

\section{B. Statutory Analysis: The Effect of the Patriot Act}

The FISCR held that the Patriot Act, by adding the relational term ("significant purpose"), eliminates the justification for the FISC to

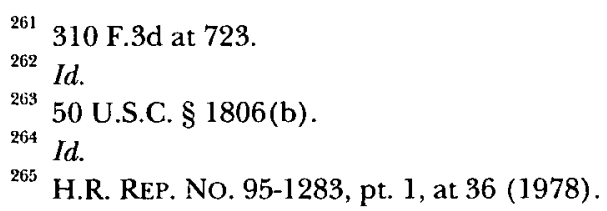


balance the relative weight of criminal prosecution and foreign intelligence purposes in determining the admissibility of FISAobtained evidence. ${ }^{266}$ The court, however, rejected the government's argument that the Patriot Act authorizes FISA investigations for any case where foreign intelligence information is a significant purpose. ${ }^{267}$ The FISCR reasoned that the intention of the $\$ 1804$ (a) (7) (B) significant purpose requirement ${ }^{268}$ is to prevent the government from targeting a foreign agent for non-foreign intelligence reasons. ${ }^{269}$ Therefore, the court limited the scope of the Patriot Act amendment to foreign intelligence information, which may include the prosecution of foreign intelligence crimes. But this distinction fails as well.

The FISCR's interpretation of the Patriot Act creates an odd distinction between law enforcement investigations primarily for foreign intelligence crimes and investigations of ordinary crimes. As stated above, the term "foreign intelligence crimes" does not encompass a precisely defined subset of crimes, but may include violation of any criminal statute of the United States. ${ }^{270}$ Under the FISCR analysis, the real distinction depends on who is committing the crime. According to the FISCR opinion then, if U.S. citizens, who are agents of a foreign power, commit any crime (even one such as perjury) it would qualify as a foreign intelligence crime. Limiting the Patriot Act to foreign intelligence crimes is essentially no limitation at all. The ruling becomes even more problematic when one considers that the term "agent of a foreign power" encompasses any U.S. person who knowingly aids and abets a foreign power. ${ }^{271}$ These definitions are broad enough to include anyone who actively supports groups like the Irish Republican Army, the Palestine Liberation Organization, and other political groups.

The FISCR foreign intelligence crime distinction is further weakened by the court's "inextricably intertwined" exception: A FISA law enforcement investigation is appropriate when ordinary crimes are "inextricably intertwined with foreign intelligence crimes."

266310 F.3d at 735 .

${ }^{267}$ Id. at 735-36; see also supra text accompanying notes 232-39 (analyzing the court's narrower interpretation of "significant purpose").

${ }^{268} 50$ U.S.C. $\$ 1804$ (a) (7) (B) requires the government to certify in the application for a FISA warrant that a significant purpose of the surveillance is foreign intelligence.

${ }^{269} 310$ F.3d at 725.

${ }^{270}$ See supra Part IV.A (discussing the problematic definition of "foreign intelligence crimes").

${ }^{271} 50$ U.S.C. $\$ 1801$ (b) (1).

${ }^{272} 310$ F.3d at 736 . 
court used, as an example of this phenomenon, international terrorists who engage in bank robberies to finance their terrorist activities. ${ }^{273}$ Under the FISCR intertwinement rationale, the government can obtain a warrant through FISA, rather than Title III, to investigate both the robberies and the terrorism. ${ }^{274}$ Without describing the standard by which "inextricably intertwined" should be measured, the court concluded that FISA "cannot be used as a device to investigate wholly unrelated ordinary crimes." ${ }^{275}$ The court's position, however, sets up a slippery slope as to how unconnected the ordinary criminal conduct must be before it is wholly unrelated to the foreign intelligence crime. Furthermore, because the exact details of terrorist plans are often unknown, it would be virtually impossible to determine the level of relatedness between the crime and the foreign intelligence purpose at the time of obtaining surveillance authorization.

\section{Constitutional Analysis: The Role of Primary Purpose in Criminal Prosecutions}

In discussing the constitutionality of the Patriot Act, the court did not decide whether a FISA warrant satisfies the Fourth Amendment warrant requirement. As stated by the FISC, there are a number of requirements that Title III, the codification of Fourth Amendment protections, imposes, but FISA does not-most importantly, probable cause of criminal activity. ${ }^{276}$ Rather than argue that FISA satisfied the Fourth Amendment, the court turned to the determination of whether the primary purpose test was constitutionally required to qualify as an exception to the Fourth Amendment. ${ }^{277}$

The issue is whether, in adding to the president's power to conduct foreign intelligence investigations, FISA remains constitutionally reasonable. ${ }^{278}$ The Truong court held the primary purpose test was the "constitutional minimum" required when applying the foreign intelligence exception without a warrant. ${ }^{279}$ The FISCR argued that since FISA adds procedures resembling warrant requirements, the minimum constitutional floor does not apply, and

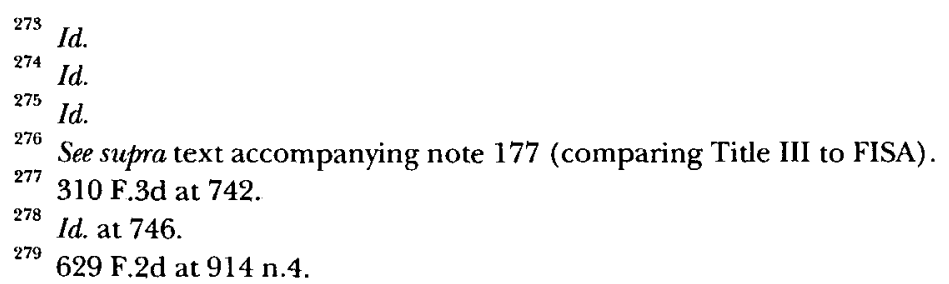


the issue instead is whether the less stringent significant purpose requirement is constitutionally reasonable. ${ }^{280}$ It seems the court's argument is that because FISA imposes a procedural framework on the government seeking to conduct surveillance, the constitutional floor can be lowered from the standard applied in warrantless surveillance. The FISCR misinterpreted the issue. Courts have recognized a foreign intelligence exception to the Fourth Amendment warrant requirement inherent in the president's constitutional power. ${ }^{281}$ It was the excessive abuse of this power by the Executive Branch, however, that prompted Congress to pass FISA. Congress was not expanding presidential power, but regulating its usage within the preexisting foreign intelligence exception. The FISCR plainly erred in holding that a validly enacted congressional statute may not encroach upon the president's "inherent" constitutional power.

Presidential foreign affairs power is not an enumerated power in the Constitution, but rather stems from the Vesting Clause, which vests the executive power of the United States in the president. ${ }^{282}$ In the famous Steel Seizure Case, Justice Jackson wrote that "presidential powers are not fixed but fluctuate, depending upon their disjunction or conjunction with those of Congress." ${ }^{283}$ In his three-part analysis, Justice Jackson stated that " $[w]$ hen the President takes measures incompatible with the expressed or implied will of Congress, his power is at its lowest ebb." ${ }^{, 84}$ In 1978, following the devastating revelations of the Church Committee, Congress deliberately acted to limit presidential power over foreign intelligence investigations. Congress was not adding to presidential foreign intelligence power, as FISCR claims, but rather carefully regulating the use of that power. The fact that FISA establishes procedural requirements that are not equivalent to traditional Fourth Amendment protections does not thereby justify broader use of the foreign intelligence exception in gathering evidence of a crime than the Constitution allows. FISA overlies the constitutional scope of the foreign intelligence exception, and a search under the former cannot be more extensive than a

280310 F.3d at 746.

${ }^{281}$ See supra Part I.C (examining how circuit courts of appeal have defined the foreign intelligence exception).

${ }^{282}$ U.S. CONST. art. II, \$ 1, cl. 1.

${ }^{283}$ Youngstown Sheet \& Tube Co. v. Sawyer, 343 U.S. 579, 635 (1952) (Jackson, J., concurring).

${ }^{284}$ Id. at 637. 
search allowable under the latter. Therefore, both Duggan and Johnson were correct in applying the primary purpose test to the application of FISA searches. ${ }^{285}$

The FISCR conflates the government's interest in foreign intelligence with its interest in subsequent criminal prosecution based on the fruits of that surveillance. In applying a balancing test between an individual's privacy interests and the government's interest, the Truong court held that during a foreign intelligence search, "the government has the greatest need for speed, stealth, and secrecy, and the surveillance in such cases is most likely to call into play difficult and subtle judgments about foreign and military affairs." ${ }^{286}$ But once the investigation is conducted primarily for criminal purposes, "courts are entirely competent to make the usual probable cause determination." ${ }^{287}$ The Truong reasoning does not falter even in cases of criminal prosecution of so-called foreign intelligence crimes.

Once the investigation becomes criminal in nature, the government should not be able to bootstrap onto the prior foreign intelligence investigation to bypass the Fourth Amendment warrant requirement. The FISCR's distinction between ordinary crimes and foreign intelligence crimes is contrary to Justice Douglas' view in Katz that "spies and saboteurs are as entitled to the protection of the Fourth Amendment as suspected gamblers." ${ }^{288}$ Applying the FISCR opinion in such cases would lead to bifurcated Fourth Amendment protection depending upon the nature of the crime. Moreover, since foreign intelligence crimes are not clearly defined, following the FISCR opinion would mean Fourth Amendment protections for U.S. citizens will vary depending upon their relationships with foreign powers-a completely anomalous result.

Most importantly, the courts have found that the constitutional basis for the foreign intelligence exception is in the president's power as commander in chief and as the sole organ in foreign affairs. As the Fifth Circuit stated in Brown, "[r]estrictions upon the President's power which are appropriate in cases of domestic security become artificial in the context of the international sphere." ${ }^{289}$ The president's foreign affairs powers are implicated in foreign intelligence

${ }^{285}$ See supra text accompanying notes 131-42 (explaining the Duggan and Johnson rulings).

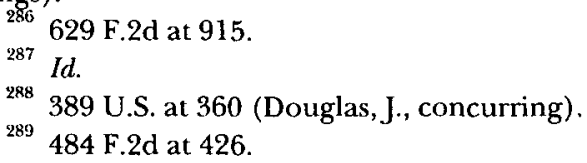


investigations because the government may decide to respond to a terrorist or foreign power threat through non-law enforcement means, including military action, covert operation, counterintelligence operation, or diplomatic measures. But once the government instead decides to follow a law enforcement strategy, those powers are not implicated, and there is no constitutional basis for a FISA law enforcement investigation.

Even if the FISCR argument is correct that foreign policy concerns do not necessarily recede once the investigation becomes primarily for law enforcement purposes, that proposition does not lead to the conclusion that law enforcement may now "direct or control" a FISA investigation to meet its objectives. Rather, if foreign policy concerns remain, a FISA investigation with a primary purpose of foreign intelligence should continue, and coordination with law enforcement should be encouraged; however, this cooperation should not extend such that FISA may be used as an end run around the Fourth Amendment. Once the foreign intelligence purpose diminishes in relation to the law enforcement purpose, the normal strictures of the Fourth Amendment should apply.

The Supreme Court's holding in Keith reaffirms this position by stating that the Fourth Amendment does apply to national security cases involving domestic organizations. Where criminal activity is involved, no matter how sensitive or serious the threat, the Supreme Court held that judges are capable of meeting their obligations without "fractur[ing] the secrecy essential to official intelligence gathering." where criminal investigations into national security threats involving domestic organizations-such as the Oklahoma City bombing-would require full Fourth Amendment warrant protections, while a similar criminal investigation involving U.S. citizens deemed "foreign agents" would not. But if the judiciary is capable of handling one circumstance, why not the other?

Congress has reaffirmed the applicability of the normal Fourth Amendment protections to sensitive national security investigations by expanding the list of predicate offenses to which Title III applies. In addition to the list of ordinary state and federal felony offenses covered by Title III, ${ }^{291}$ Congress added a set of new crimes including:

407 U.S. at 320 .

291 See 18 U.S.C. $\$ 2516(1)$ (c) (2000) (listing the ordinary offenses encompassed by Title III such as bribery, mail fraud, and obstruction of law enforcement). 
espionage, sabotage, treason, terrorism, hostage taking, destruction of aircraft, sabotage of nuclear facilities, presidential assassination, and using biological materials. ${ }^{292}$ If the normal judicial process is capable of handling law enforcement investigations of these sensitive national security crimes involving domestic organizations, the government should trust that the process is equally capable when a similar law enforcement investigation instead targets U.S. citizens who are agents of a foreign power.

Instead of looking at the clear congressional intent of FISA and the modifications to Title III, the FISCR opinion clings to the dicta in Keith that states that "[d]ifferent standards may be compatible with the Fourth Amendment.... For the warrant application may vary according to the governmental interest to be enforced and the nature of citizen rights deserving protection." was taken out of context. In Keith, the Supreme Court was addressing the issue of standards for "surveillances ... . directed primarily to the collecting and maintaining of intelligence with respect to subversive forces, and [was] not [addressing] an attempt to gather evidence for specific criminal prosecutions. ${ }^{294}$ The language upon which the government and the FISCR base their arguments is misapplied.

In sum, the result of these mischaracterizations is that the FISCR clearly erred in holding that the primary purpose test, the constitutional minimum that defines the foreign intelligence exception, could be expanded by the Patriot Act. Furthermore, the FISCR erred in finding the president had inherent constitutional authority to conduct surveillance outside the strictures of the Fourth Amendment where the purpose of the investigation was law enforcement. Finally, both Keith and the amended predicate offenses to Title III demonstrate that courts are more than capable of handling law enforcement investigations in sensitive national security matters.

\section{Constitutional Analysis: The Special Needs Doctrine}

The FISCR's last argument, relying on the Supreme Court's special needs doctrine, is equally unpersuasive. Specifically, the court held that since FISA's general programmatic purpose is "to protect the nation against terrorists and espionage threats directed by foreign powers," which is distinguishable from ordinary crime control, it falls

\footnotetext{
$292 \S 2516(1)(\mathrm{a})-(\mathrm{c})$.

293407 U.S. at $322-23$.

${ }^{294} I d$. at 318-19 (emphasis added).
} 
within the special needs doctrine..$^{295}$ But the case law does not support this holding.

The Supreme Court previously rejected the very same arguments that the FISCR upholds in its opinion. First, although the Supreme Court upheld under its special needs doctrine a roadblock, a locker search, and a drug test, the level of intrusiveness of a FISA search is exceptionally greater than these searches. ${ }^{296}$ Second, under the Patriot Act, the foreign intelligence purpose need only be significant, and therefore, law enforcement could be the primary purpose.

The Supreme Court held in City of Indianapolis v. Edmond ${ }^{297}$ that a roadblock program, whose "primary purpose... is to uncover evidence of ordinary criminal wrongdoing ... contravenes the Fourth Amendment." ${ }^{298}$ The Court warned that "the gravity of the threat alone cannot be dispositive of questions concerning what means law enforcement officers may employ to pursue a given purpose."299 Fourth Amendment protections should still apply even in the face of serious threats. Further, the fact that foreign intelligence might be a lawful secondary purpose does not suffice to make the FISA search permissible. The Supreme Court stated that if it allowed checkpoints based on "lawful secondary purposes," checkpoints would be established "for virtually any purpose so long as they also included a license or sobriety check." ${ }^{300}$ Therefore, the FISCR opinion is nothing more than rehashed special needs arguments already heard and rejected in the Supreme Court's jurisprudence.

Finally, the FISCR argued that the government's subjective purpose should not be taken into account, because intent is irrelevant to Fourth Amendment analysis. ${ }^{301}$ The Supreme Court, however, distinguished between the subjective intent of officers stopping a car and the programmatic purposes of a roadblock scheme. The Patriot Act and the 2002 Procedures, by requiring only a significant foreign intelligence purpose, not only leave open the possibility of law enforcement as a primary purpose, but actively envision surveillance and searches initiated for primarily law enforcement reasons.

${ }^{295}$ In re Sealed Case, 310 F.3d 717, 746 (Foreign Intelligence Surveillence Ct. Rev. 2002) (per curiam), cert. denied, 123 S. Ct. 1615 (2003).

${ }^{296}$ See supra note 249 (providing examples of the special needs doctrine).

${ }^{297} 531$ U.S. $32(2000)$.

298 Id. at 42.

299 Id. at 42 .

${ }^{300}$ Id. at 46.

${ }^{301} 310$ F.3d at 745 . 
Surveillance for ordinary law enforcement purposes, without the procedural protections of a warrant, probable cause, and prior judicial approval, contravenes the Fourth Amendment.

The FISCR relied on one sentence in the Edmond opinion, which states that "circumstances... may justify a law enforcement checkpoint where the primary purpose would otherwise, but for some emergency, relate to ordinary crime control." ${ }^{, 02}$ The Supreme Court used the example that "the Fourth Amendment would almost certainly permit an appropriately tailored roadblock set up to thwart an imminent terrorist attack." ${ }^{\text {03 }}$ The FISCR misinterpreted the Edmond example. The High Court was using the term "emergency," to imply imminence, not a description of the nature of the attack. It is not the general threat of a terrorist attack that permits the roadblock in the Edmond example, but the exigencies caused by the imminence of that attack. The Edmond example provides no support for a statutory framework permitting highly intrusive searches for the primary purpose of law enforcement.

\section{CONCLUSION}

On November 18, 2002, the FISCR granted the government a new and incredibly powerful tool in the war on terror at the expense of the Fourth Amendment. By upholding the Patriot Act and the 2002 Procedures, the FISCR permitted, for the first time, the use of the foreign intelligence exception to bypass the constitutional rights of U.S. citizens targeted in law enforcement investigations. The FISCR opinion is unpersuasive in arguing that the significant purpose test and the "direct or control" language of the 2002 Procedures pass statutory and constitutional muster.

First, the Court's argument fails on statutory grounds. The FISCR opinion rests on the unworkable interpretation of a "foreign intelligence crime," which is based neither in the statute, nor in the case law, nor in logic. Though the Court attempts to limit the Patriot Act's application to these newly created "foreign intelligence crimes," the limitation seems to include a violation of any criminal statute of the United States or any ordinary crime that is "inextricably intertwined" with foreign intelligence crimes.

Second, the FISCR opinion cannot survive constitutional scrutiny. 
The Court argues that the foreign intelligence exception is the constitutional minimum upon which FISA expands; however, this argument misunderstands the very nature of presidential power as defined in landmark cases like Steel Seizure. FISA overlies the foreign intelligence exception of the Fourth Amendment, and a search under the former cannot be more extensive than a search allowable under the latter. Lastly, the Patriot Act cannot find justification under the special needs doctrine because it permits investigations whose purpose is primarily ordinary law enforcement.

Administration supporters argue that the FISC provides appropriate Fourth Amendment oversight of a neutral and detached magistrate. It is clear, however, that from the limited discretion provided to FISC judges and the minimal scrutiny by which Congress intended them to review applications, the FISC does not meet constitutional standards. According to the attorney general's annual reports, from 1979 to 2001, "the FISC approved without modification 14,031 out of 14,036 applications, or $99.96 \%$ of the total." ${ }^{304}$ With minimal scrutiny applied at the FISC level and errant decisions at the FISCR, U.S. citizens are left with very little protection against the everincreasing national security power of the government and a return of the pre-Church Committee days. Our liberty is too high a price to pay for this kind of security.

304 Brief of Amicus Curiae National Association of Criminal Defense Lawyers at 30, In re Sealed Case, 310 F.3d 717 (2002) (Nos. 02-001, 02-002) (Foreign Intelligence Surveillance Ct. Rev. 2002) available at http://www.nacdl.org/public.nsf/ 2cdd02b415ea3a64852566d6000daa79/terrorism1/\$FILE/FISCRAmicus.pdf. 